\title{
THE U.N. CONVENTION ON THE RIGHTS OF PERSONS WITH DISABILITIES (CRPD): SOME OBSERVATIONS ON U.S. PARTICIPATION
}

\author{
Thomas D. Grant* \\ I. INTRODUCTION
}

The U.N. Convention on the Rights of Persons with Disabilities (CRPD) is an international instrument springing, inter alia, from the recognition that "discrimination against any person on the basis of disability is a violation of the inherent dignity and worth of the human person." 1 The text of the Convention resulted from a number of years of drafting work and input from States and non-governmental organizations. ${ }^{2}$ The text was adopted by consensus in the General Assembly on December 13, 2006. ${ }^{3}$ The Convention entered into force in accordance with Article 45, paragraph 1, upon receipt by the depository of the twentieth ratification on May 3, $2008 .^{4}$

The United States, though it did not participate as a member of the Ad Hoc Committee in drafting the Convention, sent an observer and furnished substantial input during the Committee's proceedings. ${ }^{5}$ The United States joined the consensus in the General Assembly ${ }^{6}$ and on July 30, 2009 signed the Convention. ${ }^{7}$ On May 17, 2012, the President of the United States

\footnotetext{
* Research Associate, Lauterpacht Centre for International Law; Senior Research Fellow, Wolfson College, University of Cambridge; BA, Harvard; JD Yale; PhD, Cambridge; admitted, MA, NY, District of Columbia. The author in 2008 served as a policy advisor on the national campaign headquarters staff of Republican presidential nominee John S. McCain and, inter alia, briefed the campaign on the question of U.S. participation in the CRPD. The author thanks Ron McCallum and Michael Stein for comments on drafts of the article, and Stuti Kochhar for substantive assistance on the 2013 Senate proceedings and editorial work throughout. For academic year 2013-14, the author was a W. Glenn Campbell and Rita Ricardo-Campbell National Fellow and Edward Teller Fellow at the Hoover Institution, Stanford University. The views set out in the present article are those of the author and do not necessarily reflect the views of any organization or other person.

${ }^{1}$ Convention on the Rights of Persons with Disabilities pmbl. If (h), May 3, 2008, 2515 U.N.T.S. 3, 70 [hereinafter Convention Disabilities].

${ }^{2}$ In the framework of an Ad Hoc Committee established by G.A. Res. 56/583/Add.2, ๆ 1, U.N. Doc. A/56/583/Add.2 (Dec. 19, 2001), which met from 2002 to 2006.

${ }^{3}$ G.A. Res. 61/106, U.N. Doc. A/RES/61/106 (Dec. 13, 2006).

${ }^{4}$ Convention Disabilities, supra note 1.

${ }^{5}$ See G.A. Res. 61/76, U.N. Doc. A/61/PV.76, at 6 (Dec. 13, 2006) (observations of Mr. Miller (U.S.)).

${ }^{6}$ Id.

${ }^{7}$ Kareem Dale, Valerie Jarrett \& Ambassador Rice at the U.S. Signing of the UN Convention on the Rights of Persons with Disabilities, White House Office of Pub. Engagement (July 30, 2009, 7:26 PM), http://perma.cc/77BU-NX72.
} 
transmitted the Convention to the U.S. Senate for ratification. ${ }^{8}$ The proposed resolution of advice and consent to ratification of the CRPD was not accepted by the Senate. ${ }^{9}$ With no further action taken by the adjournment of the 112th Congress, the treaty was referred automatically back to the Committee on Foreign relations. ${ }^{10}$ On November 5 and 21, 2013, the Committee held further hearings on the Convention. ${ }^{11}$ And on July 22, 2014, the Committee reported favorably on Convention. ${ }^{12}$ As of the time the present article went to press, the United States was not a party. ${ }^{13}$ To date, 146 States and the European Union have become parties to the Convention. ${ }^{14}$

The CRPD creates substantive obligations for States parties to establish and maintain national legislation protecting the rights of persons with disabilities. In addition, the CRPD establishes an institutional and procedural framework. In particular, CRPD Articles 34, 35, and 40 provide for, respectively, a Committee on the Rights of Persons with Disabilities, international reporting requirements, and a Conference of States Parties.

In adopting the CRPD, the U.N. General Assembly included an Optional Protocol to the Convention, which establishes the competence of the Committee on the Rights of Persons with Disabilities to "receive and consider communications from or on behalf of individuals or groups of individuals subject to its jurisdiction who claim to be victims of a violation by that State Party of the provisions of the Convention." 15 The Optional Protocol, in accordance with Article 13(1) therein, entered into force the

\footnotetext{
${ }^{8}$ Message from the President of the United States Transmitting the Convention on the Rights of Persons with Disabilities, S. Treaty Doc. No. 112-7, 112th Cong. (2nd Sess. 2012), available at http://perma.cc/7V2X-5H3N [hereinafter Letter of Transmittal]. Article II, Section 2 of the Constitution of the United States requires the approval of two-thirds of the Sentate for ratification of a treaty. For a review of the history of practice under Article II, Section 2, see Jean Galbraith, Prospective Advice and Consent, 37 Yale J. Int'l L. 247 (2012); Michael J. Glennon, The Senate Role in Treaty Ratification, 77 Am. J. Int'l L. 257, 258 (1983); R. Earl McClendon, The Two-Thirds Rule in Senate Action upon Treaties, 1789-1901, 26 Am. J. Int'l L. 37 (1932) (discussing early practices).

${ }^{9}$ S. Treaty Doc. No. 112-7, 112th Cong., (Dec. 4, 2012), record vote number 219 (61 yeas; 38 nays).

${ }^{10}$ In accordance with Standing Rule XXX, § 2, S. Doc. No. 113-18, at 43.

11 See Legislative Actions on Treaty Doc. 112-7, 112th Cong. (2012), available at http://perma.cc/9GPD-FJ7T (last visited July 24, 2014).

${ }^{12} \mathrm{Id}$.

13 See John R. Crook, ed., Contemporary Practice of the United States Relating to International Law, 107 AM. J. INT’L L. 207, 248 (2013), further to the Dec. 4, 2012 Senate vote.

14 Status of Multilateral Treaties Deposited with the Secretary-General Convention Disabilities, ch. IV: Human Rights: Convention on the Rights of Persons with Disabilities, U.N. TREATY Collection, http://perma.cc/697R-P8D5.

15 Optional Protocol to the Convention on the Rights of Persons with Disabilities art. 1(1), May 3, 2008, 2518 U.N.T.S 283, at 296 [hereinafter Optional Protocol].
} 
same day as the Convention. ${ }^{16}$

The CRPD is open for signature by "all States and by regional integration organizations.” ${ }^{17}$ The Optional Protocol is open for signature by any State or regional integration organization that already has signed the CRPD. ${ }^{18}$ CRPD Article 43 provides that signatories, through ratification or other formal means of consent, agree to the Convention as binding. ${ }^{19}$ Optional Protocol Article 11 likewise subjects the Optional Protocol to ratification. ${ }^{20}$ Under the general law of treaties, the drafters may, if they choose, specify how a State or other entity (e.g., an international organization) consents to be bound by the treaty. ${ }^{21}$ Because the drafters of the CRPD have specified that ratification or other formal means of consent after signature is necessary for a signatory to become a party, signature alone does not make the signatory a party to the CRPD.

A signature may, of course, indicate a State's intent to become a party, so long as the State has not expressly asserted the contrary. This follows from the specific obligations a State assumes by signing a treaty subject to ratification. Where a treaty is subject to ratification, a State that has signed the treaty is obliged "to refrain from acts which would defeat the object and purpose of [the] treaty" until such time that it has "made its intention clear not to become a party to the treaty." 22 The United States is a signatory to the CRPD but as yet has not made clear an intention not to become a party. The United States is therefore obliged to refrain from acts that would defeat the object and purpose of the Convention. In light of the United States' long practice in the field of human rights and, in particular, its strong protections for the rights of persons with disabilities, it would be surprising if the United States were to breach that obligation. ${ }^{23}$

There is, then, no real question of potential breach pending a future ratification of the CRPD by the United States. The question instead is what were the legal objections to U.S. participation in the Convention, and what

${ }^{16} I d$. at 299.

${ }^{17}$ Convention Disabilities, supra, note 1, art. 42, at 94. The Convention defines "regional integration organization" to be "an organization constituted by sovereign States of a given region, to which its member States have transferred competence in respect of matters governed by this Convention.” Id. art. 44, at 95 . It is the first of the U.N. human rights conventions to be open to such organizations.

${ }^{18}$ Optional Protocol, supra note 15, art. 10 at 298.

${ }^{19}$ Convention Disabilities, supra note 1, art. 43 at 95.

${ }^{20}$ Optional Protocol, supra note 15, at 298.

21 Vienna Convention on the Law of Treaties art. 11, May 23, 1969, 1155 U.N.T.S. 335 [hereinafter Vienna Convention].

${ }^{22}$ Id. art. 18 , at 336.

23 The rather general references to the CRPD in domestic litigation to date have not substantiated a breach of the obligations of the United States as a signatory. See e.g., human rights groups' amicus curiae submission in Smith et al v. City of Detroit, Bankruptcy Case No. 13-53846, Ad. Proc. No. 14-04732, Feb. 3, 2015. 
answers might be given in response if the U.S. Senate were to consider it again? This is not the first time that a treaty, in which the United States had taken an interest at the drafting stage, failed to receive consent for ratification on transmittal to the Senate. ${ }^{24}$ Political considerations may explain the objections in the U.S. Senate to the Convention, as much as to any treaty that has failed to receive the requisite two-thirds majority. ${ }^{25}$ Nevertheless, Senators and expert witnesses arguing against U.S. participation expressed views as to the legal effects participation would entail. That is to say, objections were expressed not only on political grounds but also in terms of the proper interpretation of provisions of the CRPD text. To arrive at a complete picture of the prospects for U.S. ratification of the CRPD, therefore, the legal arguments must be given due regard.

Critics of the CRPD, at the start, objected in respect of abortion (early termination of pregnancy) ${ }^{26}$ and the role of human rights law in armed conflict. ${ }^{27}$ To these were later added objections that the Convention, in particular its institutional apparatus, would impose an unjustifiable compliance burden; ${ }^{28}$ it might erode existing protections under U.S. law; ${ }^{29}$ and it might affect the rights of families to choose the manner in which they educate their children. ${ }^{30}$ This last objection became a focal point for critics in the Senate proceedings and also in the general political media.

This article considers the objections raised against U.S. participation in the CRPD and to evaluate these objections as a matter of treaty interpretation. The article begins with a brief overview of the drafting history of the CRPD.

\footnotetext{
${ }^{24}$ See U.N. Convention on the Law of the Sea, adopted Dec. 10, 1982, 1833 U.N.T.S. 397 (entered into force Nov. 16, 1996), which the U.S. Department of State in 2007 described as having been "a victory for U.S. diplomacy" at the time of its adoption; Dep't of State Press Statement No. 2007/967, Law of the Sea Convention (Nov. 5, 2007), cited by Law of the Sea Treaty Reported Out of Committee; Timing and Prospects for Full Senate Action Unknown, 102 AM. J. INT'L L. 168, 168-69 (2008); Statute of the International Criminal Court, July 17, 1998, 2187 U.N.T.S. 3 [hereinafter Rome Statute], about which see generally Sean D. Murphy, U.S. Notification of Intent not to Become a Party to the Rome Statute, 96 AM. J. INT'L L. 724 (2002).

${ }^{25}$ On the politics of Senate advice and consent in the matter of treaties generally, see Terry L. Deibel, The Death of a Treaty, 81 ForeIgn AfF., Sept.-Oct. 2002, at 142. On the politics of reservations practice, see David Auerswald \& Forrest Maltzman, Treaty-Making Through Advice and Consent: Treaty Consideration by the United States Senate, 65 J. PoL. 1097 (2003). As to the December 3, 2012 vote on the CRPD, from a supporter and a critic, respectively, compare Human Rights Watch, U.S.: Senate Misses Opportunity on Disability Convention, HufFInGTON Post (Dec. 5, 2012, 11:11 AM), http://perma.cc/Q6LA-9XUE; with Eric Posner, Why the U.S. Shouldn't Sign on to Empty Human Rights Treaties, SLATE (Dec. 21, 2012, 7:22 AM), http://perma.cc/J77E-EG66.

${ }^{26}$ Convention Disabilities, supra note 1, at Arts. 10, 25(A). See infra Part IV, A.

${ }^{27}$ Convention Disabilities, supra note 1, at Pream. $((\mathrm{U})$, Art. 11. See infra Part IV, B.

${ }^{28}$ Convention Disabilities, supra note 1, at Arts. 34-40. See infra Part IV, C.

${ }^{29}$ Convention Disabilities, supra note 1, at Art. 4(1). See infra

${ }^{30}$ Convention Disabilities, supra note 1, at Art. 7(2). See infra Part IV, E.
} 
It then relates the CRPD to the other U.N. human rights instruments, including those to which the United States is a party. Turning to the objections, the article considers, in light of the proper interpretation of the text, whether the critics have identified justifiable grounds for avoiding the obligations entailed by ratification. The article closes with some policy considerations in respect of the CRPD and proposes how the objections, to the extent they are based on valid concerns, might be addressed as a matter of U.S. treaty practice.

\section{DRAFTING HISTORY OF THE CRPD}

On December 19, 2001, the U.N. General Assembly adopted Resolution (GA Res) 56/168, establishing an Ad Hoc Committee to

consider proposals for a comprehensive and integral international convention to promote and protect the rights and dignity of persons with disabilities, based on the holistic approach in the work done in the fields of social development, human rights and non-discrimination and taking into account the recommendations of the Commission on Human Rights and the Commission for Social Development. ${ }^{31}$

This was an authorization by the General Assembly for the purpose of codifying international law. ${ }^{32}$ Appropriately, in light of the subject matter, the General Assembly called on the Ad Hoc Committee to take into account recommendations of two functional bodies subsidiary to the Economic and Social Council (ECOSOC): the Commission on Human Rights, and the Commission for Social Development. Pursuant to the resolution, the Ad Hoc Committee was open to "all Member States and observers of the United Nations" and would meet from 2002 to 2006 in eight sessions. ${ }^{33}$ Luis Gallegos Chiriboga (Ecuador) would chair the first five sessions and Don MacKay (New Zealand) would chair the subsequent three. ${ }^{34}$

${ }^{31}$ G.A. Res. 56/168, ๆ 1, U.N. Doc. A/RES/56/168 (Dec. 19, 2001).

32 See U.N. Charter art. 13(1).

${ }^{33}$ G.A. Res. 56/168, supra note 31, at 91.

${ }^{34}$ Rep. of the Ad Hoc Comm. on a Comprehensive and Integral International Convention on Protection and Promotion of the Rights and Dignity of Persons with Disabilities, ๆ 4, 1st Sess., Jul. 29-Aug. 9, 2002, U.N. Doc. A/57/357 (Aug. 9, 2002) [hereinafter Ad Hoc Comm., 1st sess.]; Rep. of the Ad Hoc Comm. on a Comprehensive and Integral International Convention on Protection and Promotion of the Rights and Dignity of Persons with Disabilities, ๆ 7, 2d Sess., June 16-27, 2003, U.N. Doc. A/58/118 \& Corr.1 (July 3, 2003) [hereinafter Ad Hoc Comm., 2nd sess.]; Rep. of the Ad Hoc Comm. on a Comprehensive and Integral International Convention on Protection and Promotion of the Rights and Dignity of Persons with Disabilities, I 6, 3d Sess., May 24-June 4, 2004, U.N. Doc. A/AC.265/2004/5 (June 9, 2004) 
Before the start of the second session of the Ad Hoc Committee, ${ }^{35}$ the General Assembly invited regional commissions, intergovernmental and non-governmental organizations, national disability and human rights institutions, and independent experts with interests in the topic "to make available to the Ad Hoc Committee suggestions and possible elements to be considered in the proposals for a convention." 36

States, of course, played an important role in drafting the CRPD. However, a considerable number of non-governmental organizations (NGOs) also took part. Absent restrictions under international law, the participation of non-State entities in the treaty-drafting process is not per se remarkable; however, the scope of their involvement here is noteworthy. One participant referred to the drafting of the CRPD as "the most inclusive process that the U.N. has seen." ${ }^{37}$ Ambassador MacKay estimated that seventy percent of the text originated in proposals by NGOs. ${ }^{38}$ It may be asked whether the drafting of any major international treaty before the CRPD had involved non-State participation to such a degree and whether this reflects an emerging trend. ${ }^{39}$ The first session of the Ad Hoc Committee

[hereinafter Ad Hoc Comm., 3d sess.]; Rep. of the Ad Hoc Comm. on a Comprehensive and Integral International Convention on Protection and Promotion of the Rights and Dignity of Persons with Disabilities, ๆ 6, 4th Sess., Aug. 23-Sept. 3, 2004, U.N. Doc. A/59/360 (Sept. 14, 2004) [hereinafter Ad Hoc Comm., 4th sess.]; Rep. of the Ad Hoc Comm. on a Comprehensive and Integral International Convention on Protection and Promotion of the Rights and Dignity of Persons with Disabilities, ๆ 6, 5th Sess., Jan. 24-Feb. 4, 2005, U.N. Doc. A/AC.265/2005/2 (Feb. 23, 2005) [hereinafter Ad Hoc Comm., 5th sess.]; Rep. of the Ad Hoc Comm. on a Comprehensive and Integral International Convention on Protection and Promotion of the Rights and Dignity of Persons with Disabilities, ๆ 6, 6th Sess., Aug. 1-12, 2005, U.N. Doc. A/60/266 (Aug. 17, 2005) [hereinafter Ad Hoc Comm., 6th sess.]; Rep. of the Ad Hoc Comm. on a Comprehensive and Integral International Convention on Protection and Promotion of the Rights and Dignity of Persons with Disabilities, ๆ 6, 7th Sess., Jan. 16-Feb. 3, 2006, U.N. Doc. A/AC.265/2006/2 (Feb. 13, 2006) [hereinafter Ad Hoc Comm., 7th sess.]; Interim Rep. of the Ad Hoc Comm. on a Comprehensive and Integral International Convention on Protection and Promotion of the Rights and Dignity of Persons with Disabilities, 97 , 8th Sess., Aug. 14-25, 2006, U.N. Doc. A/AC.265/2006/4 (Sept. 1, 2006) [hereinafter Ad Hoc Comm., 8th sess.].

35 The first session (July 29 to Aug. 9, 2002) was taken up with general discussion and procedural matters, including the important one of NGO participation, see infra note 40, U.N. Doc. A/57/357 (Aug. 9, 2002).

${ }^{36}$ G.A. Res. 57/229, ๆ 7, U.N. Doc. A/RES/57/229 (Dec. 18, 2002).

${ }^{37}$ Arlene S. Kanter, The Promise and Challenge of the United Nations Convention on the Rights of Persons with Disabilities, 34 SyRACUSE J. INT'L L. \& CoM. 287, 308 (2007). See also, Janet E. Lord, Disability Rights and the Human Rights Mainstream: Reluctant Gatecrashers?, in International Struggle fOr New Human Rights 83 (Clifford Bob, ed., 2009).

38 Stefan Trömel, A Personal Perspective on the Drafting History of the United Nations Convention on the Rights of Persons with Disabilities, 1 EUR. Y.B. OF DiSABILITY L. 115, 117 (2009).

${ }^{39}$ See Tara J. Melish, The UN Disability Convention: Historic Process, Strong Prospects, and Why the U.S. Should Ratify, 14 Hum. RTs. BriEF, Winter 2007, at 37; see also, Ad Hoc Comm., 
(2002) addressed modalities for the participation of accredited NGOs, albeit with the reservation that their participation "shall in no way create a precedent for other ad hoc committees of the General Assembly." "40 If a trend is to emerge in this regard, it evidently will require further political decisions. NGO participation to this degree has not become entrenched as of right.

The Ad Hoc Committee established a Working Group for the purpose of producing a draft text. ${ }^{41}$ The Working Group, ${ }^{42}$ which held meetings between January 5 to 16, 2004, included government representatives of the following States:

Cameroon
Canada
China
Colombia
Comoros
Ecuador
Germany
India
Ireland
Jamaica
Japan
Lebanon
Mali
Venezuela.

Mexico

Morocco

New Zealand

Philippines

Republic of Korea

Russian Federation

Serbia and Montenegro

Sierra Leone

Slovenia

South Africa

Sweden

Thailand

Uganda

The United States, although lacking a Working Group representative, ${ }^{43}$ submitted details of U.S. disability rights law to the committee ${ }^{44}$ and observed proceedings. ${ }^{45}$ The Working Group also included representatives of the following NGOs and national human rights institutions: ${ }^{46}$

Disability Australia Limited

Disabled Peoples’ International

Disabled Peoples' International (Africa)

2nd sess., supra note 34, at 15 (indicating that the working procedures of the Ad Hoc Committee "shall in no way create a precedent for other Ad Hoc Committees”).

${ }^{40}$ U.N. Doc. A/57/357, at 910 (Aug. 9, 2002).

${ }^{41}$ Melish, supra note 39, at 47 n.3.

42 Rep. of the Working Group to the Ad Hoc Comm., Annex 1, U.N. Doc. A/AC.265/2004/WG/1, Jan. 5-16, 2004 (Jan. 27, 2004) [hereinafter Working Group].

${ }^{43} \mathrm{Id}$. at 9 2. For an account of the role of the United States in the sessions of the Ad Hoc Committee and the domestic politics leading to U.S. participation, see JULIE A. MERTUS, BAIT AND Switch: HumAn Rights AND U.S. Foreign Policy, 178-81(2nd ed. 2008).

${ }^{44}$ Working Group, supra note 42, at 97.

${ }^{45}$ Id., at Daily Summary Vol. 3, \# 4, Jan. 8, 2004, 13.

${ }^{46}$ U.N., Membership: Ad Hoc Committee Rights of Persons with Disabilities (last visited Jun.

8, 2015), http://www.un.org/esa/socdev/enable/rights/ahcwg.htm\#membership 


\begin{abstract}
European Disability Forum
Inclusion International

Inter-American Institute on Disability

Landmine Survivors Network

Rehabilitation International

World Blind Union

World Federation of the Deaf

World Federation of the Deafblind

World Network of Users and Survivors of Psychiatry

South African Human Rights Commission.
\end{abstract}

With input from this varied community of States and NGOs, the Working Group adopted a draft text in early 2004, prompting deliberations in the Ad Hoc Committee through its seventh session. ${ }^{47}$ On August 25, 2006, the Ad Hoc Committee, in its Eighth Session, adopted the draft text of the CRPD and the Optional Protocol. ${ }^{48}$ The Ad Hoc Committee transmitted the draft text to the General Assembly on December 5, 2006. ${ }^{49}$

Following adoption by the General Assembly on December 13, 2006, the CRPD and the Optional Protocol were opened for signature on March 30, $2007 .{ }^{50}$ The United Nations indicated that more States signed the CRPD on the day it was opened for signature than any other multilateral instrument. ${ }^{51}$ Both the Convention and the Optional Protocol entered into force on May 3, $2008^{52}$. This was the fastest a multilateral convention had ever gone from initial drafting stages to entry into force. ${ }^{53}$

The drafting of the CRPD produced a considerable record. ${ }^{54}$ Under Article 32 of the Vienna Convention, the travaux préparatoires may be relevant when interpreting a treaty. ${ }^{55}$ The travaux may be used either to confirm the meaning of a treaty provision when applying the general rule of interpretation, or to determine meaning where application of the general rule

${ }^{47}$ See Ad Hoc Comm., 7th sess., supra note 34.

${ }^{48}$ Final Rep. of the Ad Hoc Comm. on a Comprehensive and Integral International Convention on the Protection and Promotion of the Rights and Dignity of Persons with Disabilities, I 1 , 8th Sess., U.N. Doc. A/61/611 (Dec. 6, 2006).

${ }^{49} \mathrm{Id}$. at 9 7. See also id., at add. 1; Ad Hoc Comm., 8th sess., supra note 34.

${ }^{50}$ In accordance with G.A. Res. 61/106, ๆ 2, U.N. Doc. A/RES/61/106 (Dec. 13, 2006).

${ }^{51}$ Kanter, supra note 37, at 288 n.5 (citing Optional Protocol, supra note 15)

${ }^{52}$ U.N. NEWS CENTRE, Landmark UN Treaty on Rights of Persons with Disabilities Enters into $\begin{array}{lll}\text { Force (May 2008), } & \text { 3, }\end{array}$ http://www.un.org/apps/news/story.asp?NewsID=26554\#.VRr3lflQNJA

53 See, e.g., Convention Disabilities, supra note 1 ("[T] treaty.”).

54 Ad Hoc Committee on a Comprehensive and Integral International Convention on the Protection and Promotion of the Rights and Dignity of Persons with Disabilities, U.N. ENABLE, http://perma.cc/H88V-B3G8.

${ }^{55}$ See Vienna Convention, supra note 21, at 340. 
leaves the provision ambiguous or obscure or would lead to a manifestly absurd or unreasonable result. ${ }^{56}$ The interpretative value of the preparatory work therefore depends, in part, on what questions arise in the course of the treaty's implementation.

The preparatory work may also record particular concerns or controversies that arose during the drafting process, revealing certain treaty provisions that are likely to generate disagreement in the future. For example, an interpretative statement that had been set out by a State representative during the drafting process could be referred to later to challenge a State's adoption of a position contrary to that statement.

The preparatory work of the treaty also may help judge the credibility of later objections to the treaty text. Where an objection is based on a certain interpretation of the text, but that interpretation is neither obvious on the face of the text nor easily deducible from the drafting work, then the credibility of the objection may be called into question. Conversely, where at least some drafters thought that the text supports the proposed interpretation, an objection on that basis would be more credible.As a matter of legal policy, it would accordingly be more justifiable for national authorities with competence over conclusion and ratification of treaties to take the objection into consideration. Some of the objections against U.S. ratification of the CRPD will be considered belowin light of the travaux préparatoires, as well as in light of the treaty text.

\section{THE CRPD IN THE U.N. HUMAN RIGHTS FRAMEWORK}

In drafting the CRPD, the Ad Hoc Committee compiled a list of international norms and standards relating to disability. ${ }^{57}$ In January 2004, Members of the Working Group noted that existing international instruments, both binding and non-binding, were relevant to the codification of an international disabilities régime. Attention was drawn specifically to the following:

- International Covenant on Economic, Social and Cultural Rights (articles 2(3), 22 and 23);

- Convention on the Rights of the Child (preamble and article 4);

- The Standard Rules for the Equalization of Opportunities for Persons with Disabilities (rule 22);

- General Comment No. 5 of the Committee on Economic, Social and Cultural Rights; and

- Environmental treaties; the Convention against Corruption; and the Ottawa Convention on prohibition of landmines. ${ }^{58}$

${ }^{56} I d$.

${ }^{57}$ Compilation of International Norms and Standards Relating to Disability, Ad Hoc Comm., 1st Sess., U.N. Doc. A/AC.265/CRP.1 (Oct., 2003), http://perma.cc/5K6H-PUP9.

${ }^{58}$ Working Group, supra note 42, at Annex 2, ๆ 8 (summary of discussions). 
Of these instruments, the Standard Rules are of particular relevance. The General Assembly adopted the Standard Rules in $1993^{59}$ on the basis of a report of the Third (Social, Humanitarian \& Cultural) Committee. ${ }^{60}$ The Standard Rules are non-binding; however, they set out principles similar to the provisions later incorporated into the CRPD. The Standard Rules also established a monitoring mechanism, which consisted of a Special Rapporteur who oversaw compliance within "the framework of the sessions of the Commission for Social Development." 61 In addition, the Rules instituted a panel consisting, inter alia, of ECOSOC-accredited experts representing the interests of persons with disabilities. A goal behind the CRPD was to turn the content of the non-binding Standard Rules into a binding international commitment. The CRPD drafters, noting the existing Special Rapporteur, also aimed to develop the institutional framework for compliance monitoring.

Drafters of the CRPD also considered how the Convention would relate to the existing U.N. framework of international human rights treaties. Each of the seven human rights treaties that came into force prior to the CRPD (and the one that came into force after its adoption) provide for the establishment of a treaty monitoring body. All nine treaties and their corresponding monitoring bodies are set out in the table below.

TABLE 1. The U.N. Human Rights Treaties and Their Monitoring

\begin{tabular}{|l|l|}
\multicolumn{1}{|c|}{ Human rights treaty } & \multicolumn{1}{c|}{ Monitoring body } \\
\hline $\begin{array}{l}\text { Convention on the Elimination of } \\
\text { All Forms of } \\
\text { Racial Discrimination }\end{array}$ & $\begin{array}{l}\text { Committee on the Elimination of } \\
\text { Racial Discrimination (CERD) }\end{array}$ \\
\hline $\begin{array}{l}\text { International Covenant on Civil and } \\
\text { Political Rights }\end{array}$ & Human Rights Committee (CCPR) \\
\hline $\begin{array}{l}\text { International Covenant on } \\
\text { Economic, Social and } \\
\text { Cultural Rights }\end{array}$ & $\begin{array}{l}\text { Committee on Economic, Social } \\
\text { and Cultural Rights (CESCR) }\end{array}$ \\
\hline Convention on the Elimination of & Committee on the Elimination of \\
\hline
\end{tabular}

${ }^{59}$ G.A. Res. 48/96, U.N. Doc. A/RES/48/96 (Dec. 20, 1993), at 2.

60 Third Comm. Rep., 48th Sess., Oct. 19-Nov. 12, 1993, U.N. Doc. A/48/62 (Dec. 14, 1993).

${ }^{61}$ G.A. Res. 48/96, supra note 59, at 26, ๆ 2. See Janet E. Lord \& Michael A. Stein, Monitoring the Convention on the Rights of Persons with Disabilities: Innovations, Lost Opportunities, and Future Potential, 32 Hum. RTs. Q. 689, 720-21, 726 (2010).

62 G.A. Res. 2106 (XX), U.N. Doc. A/RES/2106(XX) (Dec. 21, 1965), 660 U.N.T.S. 195 (entered into force Jan. 4, 1969).

${ }^{63}$ G.A. Res. 2200A (XXI), U.N. Doc. A/RES/2200A(XXI) (Dec. 16, 1966) 999 U.N.T.S. 171 (entered into force Mar. 23, 1976) [hereinafter ICCPR].

${ }^{64}$ Adopted by id., 993 U.N.T.S. 1 (entered into force Jan. 3, 1976) [hereinafter ICESCR]. 


\begin{tabular}{|c|c|}
\hline $\begin{array}{l}\text { All Forms of Discrimination } \\
\text { against Women }^{65}\end{array}$ & $\begin{array}{l}\text { Discrimination against Women } \\
\text { (CEDAW) }\end{array}$ \\
\hline $\begin{array}{l}\text { Convention Against Torture and } \\
\text { Other Cruel, Inhuman or Degrading } \\
\text { Treatment or Punishment }\end{array}$ & $\begin{array}{l}\text { Committee against Torture } \\
(\mathrm{CAT})^{67}\end{array}$ \\
\hline $\begin{array}{l}\text { Convention on the Rights of the } \\
\text { Child }^{68}\end{array}$ & $\begin{array}{l}\text { Committee on the Rights of the } \\
\text { Child (CRC) }\end{array}$ \\
\hline $\begin{array}{l}\text { International Convention on the } \\
\text { Protection of the Rights of All } \\
\text { Migrant Workers and Members of } \\
\text { Their Families } 69\end{array}$ & $\begin{array}{l}\text { Committee on Migrant Workers } \\
\text { (CMW) }\end{array}$ \\
\hline $\begin{array}{l}\text { Convention on the Rights of } \\
\text { Persons with Disabilities }{ }^{70}\end{array}$ & $\begin{array}{l}\text { Committee on the Rights of } \\
\text { Persons with Disabilities (CRPD) }\end{array}$ \\
\hline $\begin{array}{l}\text { International Convention for the } \\
\text { Protection of All Persons from } \\
\text { Enforced Disappearance }^{71}\end{array}$ & $\begin{array}{l}\text { Committee on Enforced } \\
\text { Disappearances (CED) }\end{array}$ \\
\hline
\end{tabular}

The question of how the CRPD would fit within the matrix of treaties and monitoring bodies arose during the Convention's drafting and following its adoption. In particular, CRPD drafters expressed concern over whether the Convention contained rights or obligations that were either redundant in whole or overlapped in part with those found in the other instruments. New instruments may either incorporate rights or obligations contained in earlier ones, or include new procedures. It is a question of policy-at both the municipal and international levels — as to whether it makes sense to adopt a repetitive treaty. Nothing in general international law stops States from doing so.

Overlapping treaty rules, where States have adopted them, may have certain legal effects. For one thing, the overlap may be significant to a party

65 G.A. Res. 34/180, U.N. Doc. A/RES/24/180 (Dec. 18, 1979), 1249 U.N.T.S. 13 (entered into force Sept. 3, 1981).

${ }^{66}$ G.A. Res 39/46, U.N. Doc. A/RES/39/46 (Dec. 10, 1984), 1465 U.N.T.S. 85 (entered into force June 26, 1987) [hereinafter Convention Against Torture].

${ }^{67}$ Under Article 2 of the Optional Protocol, there is a further subcommittee against torture with a special preventative mandate. Optional Protocol to the Convention Against Torture and Other Cruel, Inhuman or Degrading Treatment or Punishment, G.A. Res. 57/199, U.N. Doc. A/RES/57/199 (Jan. 9, 2003) (entered into force June 22, 2006).

68 G.A. Res.44/25, U.N. Doc. A/RES/44/25 (Nov. 20, 1989), 1577 U.N.T.S. 3 (entered into force Sept. 2, 1990).

${ }^{69}$ G.A. Res.45/158, U.N.Doc. A/RES/45/158 (Dec. 18, 1990), 2220 U.N.T.S. 3 (entered into force July 1, 2003) [hereinafter Convention Migrant Workers].

${ }^{70}$ G.A. Res. 61/106, U.N. Doc. A/RES/61/106 (Dec. 13, 2006), 2515 U.N.T.S. 3 (entered into force May 3, 2008).

${ }^{71}$ G.A. Res. 61/177, U.N. Doc. A/RES/61/177 (Dec. 20, 2006), 2716 U.N.T.S. 3 (entered into force Dec. 23, 2010). 
presenting a case to a tribunal which holds jurisdiction over allegations of breach of one treaty but not the other.$^{72}$ The recurring appearance of the rule across different treaties may also be significant in the formation of customary international law. The law of international human rights has developed through the cumulative practice of treaty making. ${ }^{73}$ The legal effect of this practice is in one respect straightforward: it has generated a body of conventional rules binding on the States that are party to the relevant instruments. Less straightforward is how repeated occurances of a rule in different treaties affect the formation of customary international law. Treatymade rules may coincide with customary international law rules. ${ }^{74}$ It is also said that the repetitive appearance of a given rule in instruments of widespread subscription may be evidence that the rule forms part of general or customary international law. ${ }^{75}$ There is no precise standard by which to judge this evidence, and it remains uncertain what rules are customary rules of human rights. International human rights law remains largely treatymade

72 See Military and Paramilitary Activities in and against Nicaragua (Nicar. v. U.S.), Merits, Judgment, 1986 I.C.J. 14, ๆๆ 42-56 (June 27); id., Jurisdiction, Judgment, 1984 I.C.J. 392, ๆף 69-73 (Nov. 26). See also Concerning Oil Platforms (Iran v. U.S.), Judgment, 2003 I.C.J. 161, ๆๆ 39, 42 (Nov. 6); id. at 280, ๆๆ 24-32 (separate opinion of Judge Buergenthal); id. at 310, ๆ 13-14 (separate opinion of Judge Owada).

73 James Crawford, Brownlie's Principles of Public InTERnational LaW 638 (8th ed. 2012).

74 See, e.g., Dispute Regarding Navigational and Related Rights (Costa Rica v. Nicar.), Judgment, 2009 I.C.J. 213, ๆ 32 (July 13) (Costa Rica’s argument in respect to navigational rights); Certain Questions of Mutual Assistance in Criminal Matters (Djib. v. Fr.), Judgment, 2008 I.C.J. 177, I 181 (June 4) (Djibouti’s argument in respect to diplomatic privileges and immunities); Armed Activities on the Territory of the Congo (Dem. Rep. Congo v. Uganda), Judgment, 2005 I.C.J. 168, ๆ 24 (Dec. 19) (Democratic Republic of Congo’s argument in respect to human rights in time of armed conflict); Land and Maritime Boundary Between Cameroon and Nigeria (Cameroon v. Nigeria, Eq. Guinea intervening), 2002 I.C.J. 303, ๆ 25 (Oct. 10) (Cameroon's argument in respect to the use of force); Fisheries Jurisdiction Case (Spain v. Can.), Judgment, 1998 I.C.J. 432, ๆ 20 (Dec. 4) (Spain’s argument in respect to the exclusivity of the jurisdiction of the flag State over vessels on the high seas); Request for an Examination of Situation in Accordance with Paragraph 63 of the Court's Judgment of 20 December 1974 in the Nuclear Tests Case (N.Z. v. Fr.), Order, 1995 I.C.J. 288, 15 (Sep. 22) (New Zealand's argument in respect of environmental impact assessments); Passage Through the Great Belt (Fin. v. Den.), Request for Indication of Provisional Measures, Order, 1991 I.C.J. 12, I 5 (July 29) (Finland's argument in respect of transit passage through an international strait).

Though the customary rule and the treaty rule may be related, they are not necessarily the same. See Questions Relating to the Obligation to Prosecute or Extradite (Belg. v. Sen.), Judgment, 2012 I.C.J. 422, ๆ 54 (July 20) (“[T]he issue whether there exists an obligation for a State to prosecute crimes under customary international law that were allegedly committed by a foreign national abroad is clearly distinct from any question of compliance with that State's obligations under the Convention against Torture and raises quite different legal problems.")

${ }^{75}$ See generally Sir Michael Wood, Special rapporteur, First report on formation and evidence of customary international law, ILC, May 17, 2013: A/CN.4/663, p. 15 (para. 34). 
law. ${ }^{76}$ The relation between the CRPD and customary international law will be considered further below. ${ }^{77}$

From the standpoint of an American policymaker, the relevant inquiry is twofold: (1) Does the CRPD contain obligations not already contained in the treaties to which the United States is a party? And (2) would the CRPD promote the formation of customary rules? These two questions are not strictly symmetrical, for the conventional framework under the CRPD entails procedural rules that the formation of a new customary rule would not. If the CRPD establishes no new conventional rights or obligations, then ratification would impose no new substantive burden. Ratification might, even so, entail a new procedural burden-such as the burden of demonstrating compliance with CRPD mechanisms in accordance with CRPD Article 35. The absence of a new substantive burden may moderate the objection that participation entails unnecessary constraints on sovereignty. Objectors might counter by asserting that an international instrument contributing nothing of substance to the human rights regime has little merit. Objectors might further contend that, because the United States already provides legal protections to disabled persons, the treaty not only lacks new substantive rules but also introduces a procedure where none is needed.

Duplicative provisions were a problem on the minds of a number of participants. ${ }^{78}$ The Coordinator of the Ad Hoc Committee advised of "the need to avoid duplicating other international instruments dealing with legal safeguards, human rights, and administration of justice including the right to appeal, such as the Covenant on Civil and Political Rights." ${ }^{79}$ This is a problem drafters can address only imperfectly. Prior to a treaty's adoption, it is difficult to say for sure what the text will add to an existing regime. The utility of the new instrument in relation to existing treaty provisions may not come to light until there has been time for parties to apply the new instrument in practice. A convention around which little or no practice has developed would seem to have little, if any, utility. There is no clear standard, however, for judging how long to wait before concluding that lack of use is evidence that the instrument is of no use at all.

These are legal questions, and they have policy implications. A possibly duplicative text, however, was not the main objection of the CRPD's critics in the United States. To the contrary, as will be seen below, their main objection was that the Convention would impose new obligations and that some of these would have unacceptable legal consequences. It now falls to consider the objections.

\footnotetext{
${ }^{76}$ CRAWFORD, supra note 73, at 643, 644 tbl. 29.1 (“Key human rights protected.”).

${ }^{77}$ See infra Part III.

${ }^{78}$ Trömel, supra note 38, at 116.

${ }^{79}$ Ad Hoc Comm., 5th sess., supra note 34, Daily summary, Jan. 27, 2005, Vol. 6, \#4.
} 


\section{OBJECTIONS TO THE CRPD}

The United States welcomed the adoption of the CRPD by the U.N. General Assembly. ${ }^{80}$ However, in speaking through its ECOSOC representative, the United States suggested three concerns over the Convention:

(i) The provision in the CRPD concerning "reproductive health” (CRPD Article 25(a)) should not be interpreted to include a right to abortion or to encourage abortion;

(ii) The application of human rights rules and standards in

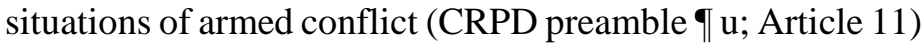
might intrude on a field already regulated by international humanitarian law; and

(iii)The rules and standards set out in the CRPD furnish less protection to persons with disabilities than U.S. legislation, thus complicating enforcement of domestic law. ${ }^{81}$

It was with reference in particular to the provisions addressing reproductive health and armed conflict that the U.S. executive branch in 2008 declined to sign the CRPD. ${ }^{82}$ It was evidently the view of the administration that the legal effects of the CRPD in these two fields would be contrary to U.S. policy, or, to the extent that the legal effects remained uncertain, were not worth the risk.

A new executive administration in 2009 reached a different view and, as noted, through the U.S. Permanent Representative to the United Nations signed the CRPD. ${ }^{83}$ However, under the system of shared powers in the U.S. Constitution, support for a treaty in the executive branch does not necessarily ensure approval for ratification. While the executive branch, by signing the Convention, indicated its willingness to bind the United States to the CRPD, several concerns arose in the Senate deliberations and in testimony before the Committee on Foreign Relations.

\section{A. CRPD Articles 10 and 25(a): "Right to Life" and "Sexual and Reproductive Health"}

In 2008, when the earlier administration declined to sign the CRPD,

\footnotetext{
${ }^{80}$ Press Release, Ambassador Richard T. Miller, Explanation of Position on the Convention on the Rights of Persons with Disabilities, Agenda Item 67(b), in the General Assembly (Dec. 13, 2006), http://perma.cc/LUG7-FPQP.

${ }^{81}$ Id.; Patrick Worsnip, U.N. Pact for Rights of Disabled Comes into Force, ReUTERs, May 3, 2008, available at http://perma.cc/P4KR-5K7Q.

${ }^{82}$ See Miller (United States), General Assembly 61 ${ }^{\text {st }}$ sess. (Dec. 13, 2006), A/61/PV.76, p. 7.

${ }^{83}$ Dale, supra note 7.
} 
and in 2012, when the Senate declined to approve its ratification, critics stated that the Convention would conflict with U.S. policy in the field of reproductive health. Two variants of the objection emerged: (1) drafters of the CRPD missed an opportunity to establish an international law rule against abortion, and (2) the CRPD implies an international law right to abortion. Article 10 and Article 25(a) were the focus of this objection and may be conveniently treated together.

Article 10 of the Convention provides as follows: "States Parties reaffirm that every human being has the inherent right to life and shall take all necessary measures to ensure its effective enjoyment by persons with disabilities on an equal basis with others." ${ }^{84}$ The chapeaux of Article 25(a) provides as follows:

States Parties recognize that persons with disabilities have the right to the enjoyment of the highest attainable standard of health without discrimination on the basis of disability. States Parties shall take all appropriate measures to ensure access for persons with disabilities to health services that are gender-sensitive, including health-related rehabilitation. In particular, States Parties shall:

a. Provide persons with disabilities with the same range, quality and standard of free or affordable health care and programmes as provided to other persons, including in the area of sexual and reproductive health and population-based public health programmes .... ${ }^{85}$

The objections to these provisions, as set out in the Senate Committee on Foreign Relations and during the drafting work, may be recalled in summary.

\section{(1) Objections to Articles 10 and 25(a)}

The statement of Minority Views in the Senate Committee on Foreign Relations recalled that "[a]bortion remains a highly controversial issue in the United States" and said that it should not be "determined . . . at an international level." 86 Noting the intensity of disagreement in the United States over abortion, Steven Groves, a fellow of the Heritage Foundation, said in the hearing on the Convention that an "'international' opinion on the matter [of abortion] from a group of disability experts ensconced in Geneva

${ }^{84}$ Convention Disabilities, supra note 1, at 101-02.

${ }^{85} \mathrm{Id}$. at 87.

${ }^{86}$ S. EXEC. ReP. No. 112-6, at 17 (2012) (minority views of Sens. Risch, Rubio, Inhofe, DeMint, and Lee). 
is unlikely to resolve or advance the debate in the United States." ${ }^{87}$ The other opposition witness, Dr. Michael Farris, Chancellor of Patrick Henry College, said in the hearing that "[i]t would reasonably appear that Article 25(a) commits the United States to providing free abortion services to persons with disabilities." ${ }^{88}$ Dr. Farris referred to this as one of the "difficulties that are latent in this treaty." ${ }^{89}$ Senator Jim DeMint, in individual remarks, also said that Article 25(a) is problematic. ${ }^{90}$

From the travaux, it is clear that the relation of Articles 10 and 25 to abortion concerned a number of participants from the early stages. The Society of Catholic Social Scientists and the Pro Life Family Coalition expressed the view that the draft text was moving in "uncharted and controversial directions" by acknowledging (at least implicitly) sexual relationships outside the context of marriage. ${ }^{91}$ The Society for the Protection of Unborn Children (SPUC) on behalf of its affiliate, No Less Human, and the Pro-Life and Pro-Family Coalition objected to the phrase "reproductive health services" on the grounds that it "includes abortion, and the treaty will be legally binding on States Parties." "92 National Right to Life (NRL) objected to the words "including sexual and reproductive health services," on the following grounds: "[Persons with disabilities] need a full range of health services, and there is no need to single out reproductive health. Doing so would promote the use of genetic testing to abort unborn babies with disabilities, and abortion for women with disabilities." ${ }^{93}$ Colombia and Qatar also expressed concern that the treaty language might be construed to promote abortion. ${ }^{94}$ Sudan, Pakistan, and Egypt preferred that the language be deleted. ${ }^{95}$ The Holy See sought to strike the words "sexual and reproductive health services" from the draft article. ${ }^{96}$ The United States, during the drafting work, objected to inclusion of the words "sexual and reproductive health" in an earlier draft article. ${ }^{97}$

The phrase adopted in the final CRPD text of Article 25, paragraph (a) is "sexual and reproductive health and population-based public health

${ }^{87}$ Id. at 97 (statement of Steven Groves, Heritage Foundation).

${ }^{88} \mathrm{Id}$. at 125 (statement of Dr. Michael Farris, Patrick Henry College).

${ }^{89} \mathrm{Id}$. at 87.

${ }^{90} \mathrm{Id}$. at 57 (statement of Sen. DeMint).

${ }^{91}$ Ad Hoc Comm., 3d sess., supra note 34, Daily summary, May 26, 2004, Vol. 4, \#4.

92 See Daily Summary, June 2, 2004, Vol. 4, \# 7 at 4.

93 Id. at 4-5.

94 Ad Hoc Comm., 5th sess, supra note 34, Daily summary, Feb. 2, 2005, Vol. 6, \# 8; Ad Hoc Comm., 6th sess., supra note 34, Aug. 8, 2005, Vol. 7, \# 6. It also was suggested by the International Right to Life Federation that privacy rights might be construed to allow abortion. Ad Hoc Comm., 5th sess., supra note 28, Feb. 3, 2005, Vol. 6, \# 9.

${ }_{95}$ Ad Hoc Comm., 7th sess., supra note 34, Jan. 25, 2006, Vol. 8, \# 8.

${ }^{96}$ Ad Hoc Comm., 3d sess., supra note 34, Daily summary, June 1, 2004, Vol. 4, \# 6.

${ }^{97}$ Ad Hoc Comm., 6th sess., supra note 34, Aug. 9, 2005, Vol. 7, \# 7. 
programmes."98 The operative words that drew objection from the United States, the Holy See, National Right to Life, and other States and groups therefore remain in the treaty as adopted.

\section{(2) Does Article 25(a) Establish a Right to Abortion in All States}

Parties?

There is no evidence in State practice that States support a uniform rule in respect to abortion. The variety of national legislation alone suggests the lack of anything approaching consensus on the topic. Nevertheless, it was a concern expressed by some of the participants during the drafting work that the CRPD might, under Article 25(a), establish an international right to abortion.

The first observation here is that Article 25(a) does not aim to create a uniform rule across national systems. Instead, Article 25(a) is concerned with equality of healthcare provisions within each national system. The United States acknowledged that equality—not uniformity—is the CRPD's concern. According to the United States, the purpose of the relevant provisions is to grant "important protections of equality for [persons with disabilities] regarding parenthood and access to information and education on family planning." ${ }^{99}$ This does not equate to replacing national legislation with an international régime.

Considering the architecture of the CRPD as a whole, it is clear that the term "other persons" under Article 25(a) refers to other persons in the national jurisdiction implementing the Convention. To suggest that the term means "other persons" in some other national jurisdiction would mean that Article 25(a) is to be applied differently from any other provision in the CRPD. The Convention is clear that every State has developed its own legal framework in the fields that concern persons with disabilities. It makes allowance, for example, for different levels of economic development. ${ }^{100}$ It also makes allowance for different national laws covering health insurance, life insurance, and the sanctity of the home and family. ${ }^{101}$ It would be discordant, in light of the text as a whole, to interpret the equality provision of Article 25(a) as requiring equality of treatment across all national

98 Convention Disabilities, supra note 1.

99 Ad Hoc Comm., 4th sess., supra note 34, Daily summary, Aug. 27, 2004, Vol. 5, \# 5 (emphasis added).

${ }^{100}$ E.g., Convention Disabilities, supra note 1, at art. 4, para. 2 ("[E]ach State Party undertakes to take measures to the maximum of its available resources.”) (emphasis added).

${ }^{101}$ E.g., id. at art. 25(e) (requiring State Parties to "[p]rohibit discrimination against persons with disabilities in the provision of health insurance, and life insurance where such insurance is permitted by national law ... .”) (emphasis added); id. at Article 23(1) ("Respect for home and family") (providing for "effective and appropriate measures to eliminate discrimination" in respect of "marriage, family, parenthood and relationships" under national law) (emphasis added). 
jurisdictions. The CRPD assures equality or non-discrimination within each national legal régime; it does not legislate what national regulation must provide. $^{102}$

The phrase "as provided to other persons" is also to be considered in light of the limited content of international law in this field. International law "provides" nothing at all to persons in the field of healthcare. There is no international system of social medicine. There is certainly nothing in the rather general healthcare provisions of the CRPD to suggest that that instrument introduces such a system. To suggest that it does is to impute an efficiency to the international law drafter that has utterly eluded his national law counterparts. If only a national healthcare statute (assuming a State chose to have one) could regulate its subject matter with a few lines of text! It is all the more clear in this light that Article 25(a) concerns equality under each existing national system. Article 25(a) does not create an international mandate for public-subsidized abortions.

\section{(3) Could Article 25(a) be Applied to Extend State Provision of Abortion in any State?}

In considering the terms of the treaty as a whole, what effect is achieved by the phrase "sexual and reproductive health" in Article 25(a)? The main clause in Article 25 already obliges equal provision of "free or affordable care and programmes." "103 There is no reason to conclude that the main clause's guarantee of equality of provision fails to cover any particular field. It therefore is not immediately clear why the final clause is necessary. The final clause suggests that the drafters intended "sexual and reproductive health" services to receive special attention. ${ }^{104}$ This, for a number of parties, was a ground for concern over the provision as a whole. ${ }^{105}$

The States, groups, and individuals objecting to Article 25(a) presumably share the policy goal of preventing the extension of a right to abortion. Their concern is evidently to avoid an international treaty rule that might, at least in some national systems, entitle a new class of individuals to such a right. Depending on the content of a State Party's existing national law, the equality of provision clause may potentially conflict with the objectors' policy goal. The situation in which that provision might conflict with the policy goal may be described in hypothetical terms.

A State, under its existing legislation, furnishes a number of services to disabled and non-disabled persons on an equal basis. However, this excludes

\footnotetext{
102 Writers have noted that it was national law in the States with the most developed régimes of disability rights that informed the adoption of the CRPD; see, e.g., Colleen Sheppard, Equality through the Prism of Legal Pluralism, 17 IUS GENTIUM 129, 130 (2012).

103 Convention Disabilities, supra note 1.

${ }^{104} \mathrm{Id}$.

${ }^{105}$ See supra, text for footnotes 94-98.
} 
"sexual and reproductive health" services. In this field, the national legislation discriminates by providing services to non-disabled persons but not to those with disabilities. Assuming that the "sexual and reproductive health" services includes an abortion provision, which the State withheld from persons with disabilities, then the Convention would require an adjustment in national healthcare provisions to that extent. The Convention would require the State to end the discriminatory treatment by requiring the State to furnish "sexual and reproductive health" services-including abortion-to persons with disabilities. But the necessary antecedent condition to this would be that the law already provides such services to nondisabled persons. The Convention would require a change of position under national law, but a very particular legal framework would have to exist already in order for the Convention to operate in this way. If there is a State providing abortion services (as part of a publicly supported package) to nondisabled persons, but not to persons with disabilities, then the main clause of Article 25 (a), as applied by such a State, would have the effect of requiring the extension of abortion services to an additional class of persons. This effect would arise only in a State that already provides abortions (and does so in the prohibited discriminatory way).

One of the witnesses opposing ratification in the U.S. Senate Foreign Relations Committee hearings, Steven Groves, drew attention to this possible legal effect. According to Groves, "Article 25 . . could be interpreted as ensuring that persons with disabilities are provided access to free or affordable abortions, assuming such access is provided to nondisabled persons by the state party." 106 The further assumption, for Article 25 to compel a change in national law, is that persons with disabilities do not already have "such access [as is] provided to nondisabled persons." ${ }^{107}$ So, Article 25(a) does not create an international law right to abortion for the general population. Instead, it has the potential effect, where a disparity of treatment exists under the national legislation of a State party, of removing the disparity. Again, as noted by the United States and as is visible on a plain reading of the text, this provision concerns equality of treatment between persons with disabilities and those without. Article 25(a) is not a provision for establishing an international abortion law. Its effect would be felt in a situation where a State provides public support for abortion to non-disabled persons but not to persons with disabilities. This would have a very limited effect. At any rate, the objectors did not furnish an example of national legislation that discriminates in this way. In the absence of such legislation, Article 25(a), under its proper interpretation, would not operate to extend State provision of abortion to any class of person.

106 See S. EXEC. REP. No. 112-6, supra note 86, at 96 (statement of Steven Groves, Heritage Foundation) (emphasis added).

${ }^{107}$ Id. 
Even if a State were identified in which public health care legislation withholds abortion services from persons with disabilities, it is still not clear that Article 25(a) would result in the extension of such services as of right to a new class of persons. As will now be seen, the shared understanding reached by the drafters further suggests that Article 25(a) does not go as far as the objectors argued.

\section{(4) The Shared Understanding in Respect of Abortion and Article}

As noted above, there was widespread concern among participants in the drafting of the CRPD that Article 25 might, by inference at least, establish an international law right to abortion. It is clear from the drafting history, however, that the States involved in the drafting work agreed that Article 25 establishes no such right.

The European Union, for example, stated expressly that the text legislates no international law right to abortion. ${ }^{108}$ This is a significant position. If a party ever sought to extend the meaning of Article 25 to create a new right to abortion, that party would have difficulty in identifying the source of the putative new right in the text-and would have the further difficulty of explaining why States during the drafting work plainly said that it did not. The European Union and its member States would particularly lack credibility, if any of them later said that it did.

Ambassador Miller, U.S. Representative to the U.N. Economic and Social Council, stated a similar position:

[T]he United States understands that the phrase "reproductive health" in Article 25(a) of the draft Convention does not include abortion, and its use in that Article does not create any abortion rights, and cannot be interpreted to constitute support, endorsement, or promotion of abortion. We stated this understanding at the time of adoption of the Convention in the Ad Hoc Committee, and note that no other delegation suggested a different understanding of this term. ${ }^{109}$

Faced with these clear statements of the EU and the United States, any State believing that Article 25(a) establishes access to abortion as an international legal right ought to have said something. There is no record that any delegation did; there is no record of a State taking exception to the way

${ }^{108}$ Ad Hoc Comm., 7th sess., supra note 34, Daily summary, Jan. 25, 2006, Vol. 8, \#8. Costa Rica and Uruguay expressed agreement.

${ }^{109}$ Miller, supra note 82. The Explanation is reproduced in full in Annex II to the present Observations. 
the EU or the United States described the legal effect of Article 25(a). Again, lacking a clear indication in the text itself that this was a provision intended to create a new abortion right, these statements from the drafting process are strong evidence of the proper interpretation of the provision. ${ }^{110}$

\section{(5) The Divergence Among National Rules on Abortion and "Right} to Life" Under Article 10

The other term in the CRPD that raised concern was "right to life," as contained in Article 10. ${ }^{111}$ National Right to Life (NRL), an NGO, would have preferred language clarifying the temporal scope of the "right to life" protection:

State Parties reaffirm that every human being has an inherent right to life from conception to natural death, and shall take all necessary measures to ensure its effective enjoyment by persons with disabilities on an equal basis with others, and shall ensure that disability or perceived quality of life shall not serve as a basis for the infringement of the right to life. ${ }^{112}$

If the treaty, as adopted, had contained this clause- - "from conception to natural death"- then the treaty would have established an international definition of life for purposes of right to life. NRL was not alone in seeking to establish such an international definition. Other participants in the Working Group called for a more specific provision that would prohibit "specific infringements on the right to life, such as forced or coerced abortions or practices of euthanasia." 113 Colombia suggested that "the text could prohibit the promotion of abortion on the grounds of disability." 114 Seemingly at the other end of the spectrum of views on abortion, some participants sought instead a guarantee that national legislation "would not compromise women's reproductive rights." 115 The adopted text avoids

\footnotetext{
${ }^{110}$ For an example of the legal significance of States parties' concordance in a drafting session with one State's interpretation of the text, see Concerning the Maritime Dispute (Peru v. Chile), Public Sitting Record, 2012 I.C.J., C.R. 2012/30, at 60, $\uparrow \uparrow$ 4.27-4.28 (Dec. 6, 2012) (statement of the delegate of Ecuador respecting the method of maritime delimitation, recorded in the 1954 Minutes of the Complimentary Convention, Crawford (for Chile)). 111

112 Ad Hoc Comm., 5th sess., supra note 34, Daily Summary, Jan. 27, 2005, Vol. 6, \#4 (emphasis added).

113 Working Group, supra note 42, Daily Summary, Jan. 5-16, 2004, Vol. 3, \#7 at 16 (observation by Disabled People's International). And to similar effect see id., Vol. 3, \#9 at 7. ${ }^{114}$ Id. at 17. Cf. proposal by Uganda, Ad Hoc Comm., 3d sess., supra note 34, Daily summary, May 26, 2004, Vol. 4, \#3. Kenya and Venezuela supported the proposal by Uganda. Ad Hoc Comm., 4th sess., supra note 34, Daily Summary, Aug. 26, 2004, Vol. 5, \#4.

${ }^{115} I d$. at Observation by World Network of Users and Survivors of Psychiatry.
} 
specific treatment of the problem either way, instead providing for a general "right to life." 116

Several States and other participants in the drafting work acknowledged that divergent national positions place a limit on what a multilateral convention can do in respect of abortion. Ireland, for example, a State with relatively strong protections for the unborn, noted that the difference of national approaches on the topic of "right to life" made it undesirable to incorporate a detailed definition in the draft text. ${ }^{117}$ As noted above, Article 25(a) is a guarantee of equality within a national jurisdiction, not a guarantee of a single, specific international program of "sexual and reproductive health." 118 Article 10, similarly, leaves it to individual states to legislate a "right to life." The only obligation under Article 10 is to guarantee this right to all persons, regardless of disability, within that jurisdiction. Like Article 25(a), Article 10 does not impose an international law rule that would supplant national legislation. It does not define "life" or, for that matter, what a "right to life" entails.

\section{(6) The U.S. Secretary of State's Observations on "Access to} Abortion"

Objectors to Article 25(a) drew attention to a statement by the U.S. Secretary of State, which indicated that "family planning is an important part of women's health; and reproductive health includes access to abortion." 119 The statement was in response to a question regarding the Secretary's general view of U.S. foreign policy. ${ }^{120}$ The objectors suggested that the statement supports the interpretation that Article 25(a) legislates an international right to abortion. The better view is that the Secretary's statement says nothing about how Article 25(a) should be interpreted.

When one State seeks to verify another State's position in their treaty relations, the State well may refer to statements by the other State's foreign minister.. ${ }^{121}$ The U.S. Secretary of State's statement, however, had nothing

\footnotetext{
${ }^{116}$ See also discussion in the Ad Hoc Committee respecting draft art. 8. Ad Hoc Comm., 5th sess., supra note 34, Daily summary, Jan. 24, 2005, Vol. 6, \#1.

${ }_{117}$ Working Group, supra note 42, Daily Summary, Vol. 3, \# 9, Jan. 15, 2004, at 8.

118 See Convention Disabilities, supra note 1.

${ }^{119}$ New Beginnings: Foreign Policy Priorities in the Obama Administration: Hearing Before the Senate Committee on Foreign Affairs, 111th Cong. 24 (2009); S. EXEC. REP. 112-6, supra note 86 , at 18 .

120 For the Secretary's opening and prepared statement, see U.S. Dep't of State, New Beginnings: Foreign Policy Priorities in the Obama Administration, (Apr. 22, 2009), http://perma.cc/8HFB-F7ZH.

${ }^{121}$ See, e.g., Concerning the Application of the Interim Accord of 13 September 1995 (the former Yugoslav Republic of Macedonia v. Greece), Public Sitting, Verbatim Record, 2011 I.C.J., C.R. 2011/5 at 29, 112 (March 21) (Mr. Sands for the former Yugoslav Republic of
} 
to do with the text of Article 25(a). The proceedings in which the Secretary made the statement did not address the interpretation of the CRPD, nor did they address the content of other human rights instruments or of general international law. It was not the purpose of the Secretary's statement to analyze U.S. international legal policy or to present a detailed catalogue of U.S. obligations under treaties. Instead, the Secretary's statement established, in summary fashion, the policy objectives of the United States in general. A statement iterating the general policy that motivates a particular treaty might be relevant when the object and purpose of the treaty is unclear; however, the object and purpose of the CRPD is evident. The U.S. Secretary of State's general view of foreign policy does little to elucidate the meaning of the CRPD.

There is a further observation to be drawn from the relation between Article 25(a) and national legislation. Article 25(a) obliges States parties to "[p]rovide persons with disabilities with the same range, quality and standard of free or affordable health care and programmes as provided to other persons, including in the area of sexual and reproductive health and population-based public health programmes.”122 How Article 25(a) will operate for a given State party is determinable only on the basis of what, by virtue of that State's national legislation, is "provided to other persons." 123 The U.S. Secretary of State, speaking at a Congressional hearing, does not establish what U.S. legislation provides. That is determined by reference to the United States Code and Code of Federal Regulations. The remarks of the Secretary of State do not determine how Article 25(a) would operate for the United States, if the United States were to ratify the Convention.

\section{(7) "Dignity," "Worth," and the Non-Legal Connotations of the}

Terms in a Legal Text

A range of other objections, broadly related to the protection of life, were made in addition to the objection to the abortion provision. To an extent perhaps unusual in legal drafting work, objections arose not from the legal meaning of particular terms but from the political or other connotations those terms carry in particular societies. On several occasions during the drafting process, NGOs expressed concern over the non-legal meaning or connotations of particular language. For example, the International Right to Life Federation and the Coalition for the Protection of Persons with Disabilities proposed that the words "and worth" be added to "death with

Macedonia); id., at 43, 44, 45-46, 49, ๆๆ 20, 23, 28-29, 38-40 (Mr. Murphy for the former Yugoslav Republic of Macedonia).

122 See Convention Disabilities, supra note 1.

${ }^{123}$ See Convention Disabilities, supra note 1. 
dignity” on the ground that the latter phrase, on its own, suggests support for euthanasia. According to the NGOs:

The term "death with dignity" is used by proponents of assisted suicide and euthanasia to justify the termination of a human life whose quality of life is deemed unworthy. Every human person has dignity and worth irrespective of their perceived quality of life. Persons with disabilities are particularly vulnerable because of their perceived poor quality of life and are deemed unworthy to live and better off dead. ${ }^{124}$

The fact that certain political activists - in this case, proponents of assisted suicide and euthanasia - use a term in a certain way has little or no bearing on the meaning of the term for purposes of a treaty. Neither the draft text nor the CRPD as adopted contains the phrase "death with dignity," and no party participating in the drafting established that the phrase has a specific or technical meaning for purposes of international law. The objection to the phrase in the draft text was based not on a judgment of its possible legal effect-for example, that the language might impose a certain obligation on the United States. Rather, the objection reflected the belief that the phrase had undesirable overtones. As a matter of international law, the word "dignity" in an international agreement does not impose a right to euthanasia or other such practice. Nothing like consensus in support of euthanasia exists among national systems. Nor does the phrase "death with dignity," interpreted in view of the CRPD as a whole, have anything to do with euthanasia. In the CRPD, the word "dignity" appears nine times. ${ }^{125}$ It appears twice with the words "and worth" 126 and once with the words "and selfworth." 127 None of the provisions in which the word "dignity" appears suggest, even by inference, that the drafters intended the CRPD to impose on States a new and intrusive régime in abrogation of rules concerning the most sensitive questions of morality and human relations.

This is not to say that concerns over the non-legal connotations of terms used in an international instrument are unimportant. They well may determine the prospects for ratification under national procedures in which legal analysis is only one factor.

${ }^{124}$ Ad Hoc Comm., 5th sess., supra note 34, Daily summary, Jan. 27, 2005, Vol. 6, \# 4. See also Ad Hoc Comm., 6th sess., supra note 34, Daily summary, Aug. 8, 2005, Vol. 7, \# 6, observation of Society for the Protection of Unborn Children.

125 See Convention Disabilities, supra note 1, preambular qף (a), (h), (y); Arts. 1, 3(a), 8(1)(a), 16(4), 24(1)(a), 25(d).

${ }^{126}$ See Convention Disabilities, supra note 1,.preambular १ๆ (a), (h).

127 See Convention Disabilities, supra note 1,ף 24(1)(a). 
B. Preambular Paragraph (u) and Article 11: CRPD in Armed Conflict and its Relation to International Humanitarian Law

The United States, almost from the start, made clear that it objected to the incorporation into the CRPD of any provision concerning situations of armed conflict. ${ }^{128}$ Opposition by the United States did not, however, prevent adoption of preambular paragraph (u) and Article 11, which provide as follows:

(u) Bearing in mind that conditions of peace and security based on full respect for the purposes and principles contained in the Charter of the United Nations and observance of applicable human rights instruments are indispensable for the full protection of persons with disabilities, in particular during armed conflicts and foreign occupation ....

Article 11 - Situations of risk and humanitarian emergencies

States Parties shall take, in accordance with their obligations under international law, including international humanitarian law and international human rights law, all necessary measures to ensure the protection and safety of persons with disabilities in situations of risk, including situations of armed conflict, humanitarian emergencies and the occurrence of natural disasters.

The relevant phrases are "during armed conflicts and foreign occupation" in paragraph (u), ${ }^{129}$ and "including situations of armed conflict" in Article 11. ${ }^{130}$ These provisions would appear to extend the application of the CRPD to a field covered by international humanitarian law rules, such as those contained in the 1907 Hague Convention Respecting the Laws and Customs of War on Land ${ }^{131}$ and the 1949 Geneva Conventions. ${ }^{132}$

On August 25, 2006, the Ad Hoc Committee adopted by vote a draft preambular paragraph, designated at the time as “(s) bis,” which was largely

${ }^{128}$ Ad Hoc Comm., 4th sess., supra note 34, Daily summary, Aug. 26, 2004, Vol. 5, \# 4.

129 See Convention Disabilities, supra note 1.

130 See Convention Disabilities, supra note 1.

${ }^{131}$ Hague Convention Respecting Laws and Customs of War on Land, Oct. 18, 1907, 36 Stat. 2277, 205 Consol. T.S. 277 (entered into force Jan. 26, 1910).

132 The most directly relevant to the CRPD is the Convention (IV) relative to the Protection of Civilian Persons in Time of War, Aug. 12, 1949, 6 U.S.T. 3516, 75 U.N.T.S. 287. See in particular art. 27, cl. 3, providing that "all protected persons shall be treated with the same consideration by the Party to the conflict in whose power they are, without any adverse distinction.” Id. at 6 U.S.T. at 35\#\#, 75 U.N.T.S. at 306. 
retained as preambular paragraph $(\mathrm{u})$ in the adopted text. ${ }^{133}$ The vote on the draft paragraph was 102 States in favor, 5 against, and 8 abstaining. The States voting against were Australia, Canada, Israel, Japan, and the United States. The States abstaining were Cameroon, Côte d'Ivoire, Gabon, Kenya, Niger, Nigeria, the Republic of Korea, and Serbia. The timing was inauspicious. Israel's operation against Hezbollah in Lebanon had begun the month before, and this introduced a political element in the Ad Hoc Committee's discussions of the draft paragraph. ${ }^{134}$

In the hearings before the Senate Foreign Relations Committee in 2012, the armed conflict provisions were not a focal point of objection. This is surprising since the United States had made clear, both in the drafting work and in the General Assembly at the time the Convention was adopted, that preambular paragraph (u) and Article 11 posed difficulties and should not have been incorporated into the text as drafted. The United States' position (which was shared by several of its allies) may be recalled here in brief before turning to the questions presented by the overlapping claims of human rights and humanitarian law.

\section{(1) The U.S. and Allied Position on the Armed Conflict Clauses in} the CRPD

Upon the adoption of the CRPD by the U.N. General Assembly in 2006, the United States indicated its concerns with the Convention's armed conflict provisions:

[T]he reference in this human rights Convention to armed conflict and foreign occupation, which are governed by international humanitarian law and not by human rights law, would create unnecessary legal confusion and thus potentially undermine the extensive protections already available under international humanitarian law to protected persons in those situations. The United States wishes to note for the official record its continued concerns related to that preambular paragraph in the Convention. We note that those

\footnotetext{
${ }^{133}$ Ad Hoc Comm., 8th sess., supra note 34, at 911.

134 Trömel, supra note 38, at 15 . The operation had begun on July 12, 2006, following crossborder attacks by Hezbollah. Identical letters dated July 12, 2006 from the Permanent Representative of Israel to the United Nations addressed to the Secretary-General and the President of the Security Council, U.N. Doc. A/60/937-S/2006/515 (July 12, 2006); see also S.C. Res. 1701, preamb. ๆ 2 U.N. Doc. S/RES/1701 (Aug. 11, 2006). The ensuing violence precipitated a humanitarian crisis. Identical letters dated 19 July 2006 from the Chargé d'affaires a.i. of the Permanent Mission of Lebanon to the United Nations addressed to the Secretary-General and the President of the Security Council, with Annex, Letter of the Prime Minister to the Diplomatic Corps in Beirut, U.N. Doc. A/60/948-S/2006/550 (July 19, 2006).
} 
concerns also apply to article 11 , which deals with situations of armed conflict. ${ }^{135}$

This objection is consistent with the U.S. position overall on the functions of human rights law and humanitarian law. To incorporate the former into the latter, in the view of the United States, is to introduce an "unnecessary confusion.", 136 regimes:

Israel also expressed concern over the relation between the two legal

The attempt to draw artificial parallels between two different legal regimes under international law, that of human rights law and the law of armed conflict, only undermines the effectiveness of each regime. Israel would therefore like to place on record its concern regarding references in the Convention to elements taken from the law of armed conflict. $^{137}$

The other objecting States declined to elaborate on the matter in the General Assembly but had done so already in the Ad Hoc Committee in 2006. ${ }^{138}$

This was by no means the first time that the relation between these two domains of international law had raised questions.

\section{(2) The Relation Between Human Rights and Humanitarian Law in} General

The difficulty in identifying the precise relation between human rights rules and international humanitarian law has existed for some time. When the International Court of Justice in 1996 asked for an advisory opinion on the legality of the threat or use of nuclear weapons, some States responded ${ }^{139}$ by referring to Article 6, paragraph 1, of the International Covenant on Civil and Political Rights (ICCPR), which provides that "[e]very human being has the inherent right to life. This right shall be protected by law. No one shall be arbitrarily deprived of his life.” 140 The Court in its opinion said as follows:

[T]he protection of the International Covenant of Civil and

\footnotetext{
${ }^{135}$ G.A. Res. 61/76, supra note 5, at 7 (Mr. Miller (U.S.)).

${ }^{136} \mathrm{Id}$.

${ }^{137}$ G. A. Res. 61/76, supra note 5, at 18 (Ms. Feldman (Israel)).

${ }^{138}$ Ad Hoc Comm., 8th sess., supra note 34, at 911.

139 See, e.g., Written Statement of the Government of Egypt to the U.N., June 20, 1995, at 15-16, ๆ 27.

${ }^{140}$ ICCPR, supra note 63.
} 
Political Rights does not cease in times of war, except by operation of Article 4 of the Covenant whereby certain provisions may be derogated from in a time of national emergency. Respect for the right to life is not, however, such a provision. In principle, the right not arbitrarily to be deprived of one's life applies also in hostilities. The test of what is an arbitrary deprivation of life, however, then falls to be determined by the applicable lex specialis, namely, the law applicable in armed conflict which is designed to regulate the conduct of hostilities. Thus whether a particular loss of life, through the use of a certain weapon in warfare, is to be considered an arbitrary deprivation of life contrary to Article 6 of the Covenant, can only be decided by reference to the law applicable in armed conflict and not deduced from the terms of the Covenant itself. ${ }^{141}$

So the human rights rule, by which is guaranteed "right to life," does not lapse during armed conflict. The human rights treaty, however, does not furnish the definition by which to determine whether a breach of the right has been committed; "the test of what is an arbitrary deprivation of life" is not found in the treaty. Instead, the "test" is found in humanitarian law. While suggesting an admixture of the two regimes, this approach preserves the function of humanitarian law in the proper sphere of its application.

The precise contours of the relation between human rights and the humanitarian law rules in force with respect to armed conflict remain, even in light of Nuclear Weapons, far from clear. One writer has said that the human rights rules under the World Heritage Convention ${ }^{142}$ and the ICESCR $^{143}$ are applicable when a party has committed a breach of the humanitarian rules under the 1954 Hague Convention for the Protection of Cultural Property in the Event of Armed Conflict. ${ }^{144}$ At least one national court has said that international humanitarian law is lex specialis-a body of international law rules applying in the special circumstance of armed conflict or military occupation-but that gaps in that law may be filled by reference to international human rights law. ${ }^{145}$ Where gap filling ends and substitution

\footnotetext{
${ }^{141}$ Legality of the Threat or Use of Nuclear Weapons, Advisory Opinion, 1996 I.C.J. 226, ๆ 25 (July 8) [hereinafter Legality Nuclear Weapons].

${ }^{142}$ United Nations Convention for the Protection of the World Cultural and Natural Heritage, Nov. 16, 1972, 27 U.S.T. 37, 1037 U.N.T.S. 151.

143 See ICESCR, supra note 64.

144 Ronald J. Bettauer, Book Review, 102 AM. J. INT’L L. 220, 225 (2008) (reviewing RoGER O’Keefe, The Protection of Cultural Property in Armed Conflict (2006)); Hague Convention for the Protection of Cultural Property in the Event of Armed Conflict, adopted May 14, 1954, 249 U.N.T.S. 240 (entered into force Aug. 7, 1956).

${ }^{145}$ HCJ 769/02 Pub. Comm. Against Torture in Israel v. Gov’t of Israel [2006] (Isr.).
} 
begins may be difficult in practice to determine, and to state that the two regimes relate in this way does not, in itself, provide a reliable guide to the application of their (potentially overlapping) rules. Legal writers have recognized the difficulty in determining how, if at all, human rights law applies in armed conflict, military occupation, or within the armed forces generally. ${ }^{146}$

Intermittently, international law writers in the United States have suggested that human rights law applies in armed conflict (in addition to humanitarian law). ${ }^{147}$ There are also the cases in which parties have sought to apply rights protections under U.S. constitutional law to situations of armed conflict, ${ }^{148}$ but these are not directly relevant to the relation of armed conflict to international rights protections.

\section{(3) A Shift in the U.S. Position on the Application of Human Rights Rules in Armed Conflict?}

In the last forty years, the United States, more or less consistently, has treated the two fields - human rights and humanitarian law-as distinct, with the latter prevailing in the special situation of armed conflict. According to a lawyer in the U.S. Department of State Office of the Legal Adviser in 2005,

The obligations assumed by states under the main international human rights instruments were never intended to apply extraterritorially during periods of armed conflict. Nor were they intended to replace the lex specialis of international humanitarian law. Extending the protections provided under international human rights instruments to situations of international armed conflict and military occupation offers a dubious route toward increased state compliance with international norms. ${ }^{149}$

The U.S. position has broadly followed this précis, ${ }^{150}$ and, as seen above, the United States maintained its position in its statements respecting the CRPD.

It may be, however, that since 2008 the United States has modified its

\footnotetext{
${ }^{146}$ See, e.g., Peter Rowe, The Impact of Human Rights Law on Armed Forces (2006).

${ }^{147}$ See, e.g., Martin \& Joan Kyre, Military Occupation and National Security 97 (1968).

148 See, e.g., Munaf v. Geren, 553 U.S. 674 (2008).

${ }^{149}$ Michael J. Dennis, Application of Human Rights Treaties Extraterritorially in Times of Armed Conflict and Military Occupation, 99 AM. J. INT'L L. 119, 141 (2005). See also Bettauer, supra note 144, at 225-26.

${ }^{150}$ See, e.g., Comments by the Government of the United States of America on the concluding observations of the Human Rights Committee, at 2-3, U.N. Doc. CCPR/C/USA/CO/3/Rev.1/Add.1 (Feb. 12, 2008).
} 
position. The U.S. periodic report in 2011 to the Human Rights Committee, for example, suggests that the humanitarian law rules are not so much to be applied as strictly separate from the human rights rules but, rather, as additive to them: "torture and cruel treatment in armed conflict are also prohibited by the Geneva Conventions of 1949". ${ }^{151}$ In respect of Article 11 of the CRPD, the Administration indicated that this provision is "consistent with DOD Directive 2311.01E, The Department of Defense Law of War Program.”152 These statements would suggest, instead of an absolute position segregating the two legal regimes, an acknowledgement of the potential of overlap. To acknowledge that the rules may overlap would bring the United States closer to the Wall Advisory Opinion, where the Court said that situations exist in which both humanitarian law and human rights law apply. ${ }^{153}$ If, indeed, a shift has entered U.S. legal policy on this matter, it is all the more surprising that, during the Senate Committee on Foreign Relations hearings on the CRPD, those advising against ratification declined to raise the alarm.

It is a matter of legal policy, rather than textual interpretation, whether a human rights convention ought to make provision for the application of its rules in situations of armed conflict. The text as adopted is clear enough: the CRPD in preambular paragraph (u) and Article 11 deals with situations of armed conflict. Some observations nevertheless may be made here, in respect of the questions this drafting choice may present.

\section{(4) The U.N. Human Rights Régime in Situations of Armed Conflict: Questions of Legal Policy}

First, a difficulty may arise, if a human rights treaty provides for causes of action not found in existing instruments. This will not happen where there exists neither an international instance competent to receive claims based on the human rights treaty in question nor a provision in national law for direct application of the treaty as a basis for claims in national court. However, where one or both exist, the human rights treaty well may invite claims in connection with armed conflict; and, try as national courts might to limit their scope, ${ }^{154}$ the international court seized of the claims well may decide both to exercise jurisdiction and to apply the human rights rule. ${ }^{155}$ The difficulty does

${ }^{151}$ U.S., Fourth Periodic Report of the United States of America Concerning the International Covenant on Civil and Political Rights, ๆ 171, U.N. Doc. CCPR/C/USA/4 (May 22, 2012) (emphasis added).

152 S. EXEC. REP. No. 112-6, supra note 86, at 136.

${ }^{153}$ Legal Consequences of the Construction of a Wall in the Occupied Palestinian Territory, Advisory Opinion, 2004 I.C.J. 136, \ 106 (July 9) [hereafter Legal Consequences].

154 Al-Skeini v. Secretary of State for Defence (Consolidated Appeals), [2007] UKHL 26, [2008] 1 A.C. 153 (appeal taken from Eng.); R v. Secretary of State for Defence, [2007] UKHL 58, [2008] 1 A.C. 332 (appeal taken from Eng.).

155 Al-Skeini v. United Kingdom, 53 Eur. Ct. H.R. 18 (2011); Al-Jedda v. United Kingdom, Eur. Ct. H.R. App. No. 27021/08 (2011) (holding, inter alia, that provisions of the European 
not arise, where the State party is not subject to an international dispute settlement mechanism, but it suggests a concern of principle in any event.

A second difficulty is that the application of human rights instruments may add complications to the governance of an occupied territory. This would be the difficulty, for example, presented by the Advisory Opinion of the International Court of Justice in the Wall case with respect to the West Bank. The International Court stated in the Advisory Opinion that "the International Covenant on Civil and Political Rights is applicable in respect of acts done by a State in the exercise of its jurisdiction outside its own territory." ${ }^{156}$ A significant additional treaty basis thus would be established for scrutinizing the State party's conduct.

And third, the introduction of human rights provisions into situations of armed conflict by way of an international treaty like the CRPD raises general questions of the separation of functions and powers in international institutions. The drafting process that led to adoption of CRPD was set in train by the General Assembly. The Ad Hoc Committee given the task of drafting the convention was to take into account recommendations of the Commission on Human Rights ${ }^{157}$ and the Commission for Social Development. The Commission on Human Rights was and the Commission for Social Development is a functional commission subsidiary to ECOSOC. It is the U.N. Security Council-not the General Assembly or ECOSOCthat is the main organ under the U.N. Charter concerned with international peace and security. Questions relating to the regulation and settlement of armed conflict are chiefly, then, Security Council questions. It, therefore, may be asked whether a convention drafted to protect human rights—not to regulate peace and security-is the right instrument in which to establish new rules in respect to armed conflict. The European Court of Human Rights in Al-Jedda did not see the Security Council's particular function to entail a privilege over and against the application of human rights rules ${ }^{158}$ — which suggests how, at least in one regional system, a new human rights treaty that expressly invokes situations of armed conflict and foreign occupation might introduce complications.

It would exaggerate the development of separation of powers or functions in the law of international institutions to equate it to separation of powers doctrine in U.S. constitutional law. But separation of powers is by no means alien to the U.N. system. The International Court has been clear: certain organs in the U.N. system perform certain functions, and certain

Convention on Human Rights were applicable to the conduct of UK armed forces personnel in Iraq). For comment, see Marko Milanovic, Al-Skeini and Al-Jedda in Strasbourg, 23 EuR. J. INT’L L. 121 (2012).

${ }^{156}$ Legal Consequences, supra note 153, at 9111.

157 This later was dissolved and replaced with a new Human Rights Council. G.A. Res. 60/251, U.N. Doc. A/RES/60/251 (Mar. 15, 2006).

158 See Al-Jedda, Eur. Ct. H.R. App. No. 27021/08 at 9 87-91 (summarizing the U.K. position). 
organs do not exercise certain functions. The World Health Organization, for example, did not have authority to request an Advisory Opinion concerning the legality of the use of nuclear weapons in armed conflict, on the grounds (inter alia) that such a question (which principally concerned peace and security) did not belong to the WHO's functions. ${ }^{159}$ The functions of the General Assembly, the International Court said earlier, are those expressly set out in the U.N. Charter and, for certain purposes (e.g., admission of States as new Members to the United Nations), can only be exercised in conjunction with the Security Council. ${ }^{160}$ In the "mainstream" of European human rights institutions, an objection grounded on the proper exercise of U.N. competences would have little credibility, but those institutions are not motivated by the same concerns as U.S. policy-makers, and they function under their own legal framework. The extension of CRPD into the law of armed conflict may be criticized on grounds that this is not consistent with the functions and powers of the bodies that undertook its drafting and adoption.

In any event, whatever the merits of the points above, and notwithstanding signs of a shift in recent U.S. practice, it has been the more or less consistent position of the United States that a human rights convention should not intermingle its rules with those of the law of armed conflict. This was not one of the main objections in the Senate hearings in respect of ratification of the CRPD, but it is an objection well-grounded in U.S. practice. If that position is to be maintained, then consistency with it should be maintained across the relevant international legal policies of the United States. Accordingly, if the United States is to ratify the CRPD, then the effects of preambular paragraph (u) and Article 11 should be addressed. A reservation, understanding or declaration in respect of the armed conflict clauses would be an effective means to maintain the consistent position.

The other area of application evidently envisaged for Article 11humanitarian crises other than armed conflict—would not seem to present the same questions of policy or legal consistency. ${ }^{161}$ Article 11 would not call for reservation in that connection.

\section{Articles 34-40 and the Optional Protocol: International Compliance}

\footnotetext{
${ }^{159}$ Legality Nuclear Weapons, supra note 141 , at $\uparrow 10$. See also id. at $\mathbf{q} 11,14$.

160 Competence of the General Assembly for Admission of a State to the United Nations, Advisory Opinion, 1950 I.C.J. 4 (March 3).

${ }^{161}$ See, e.g., Ron McCallum AO, Professor Emeritus, Faculty of Law, University of Sydney, Australia, Keynote Speech for the Japan Disability National Forum: International Monitoring and The Harmonisation of Domestic Law: Japan and the CRPD, at 4 (Dec. 6, 2012) ("The entire world recalls the 11 March 2011 Tsunami which tragically struck the coast of north east Japan. As was demonstrated by this disaster, persons with disabilities are vulnerable in these emergency situations.”).
} 
Burden

It was suggested several times in the Senate hearings in respect of ratification of the CRPD that the burden of complying with the international mechanisms contained in the Convention is too high to merit ratification. The statement of minority views asserted that the reporting requirement under Article 35, for example, is of unknown scope and that its "financial and labor costs to the American taxpayer" thus are uncertain as well. ${ }^{162}$ The minority views statement also said that the monitoring committee (to be established under Article 34) would likely digress into matters unrelated to the rights of persons with disabilities and make "recommendations that are contrary to the interests and values of the United States." "163 The statement referred to a report of the Committee on the Elimination of Racial Discrimination (CERD) in 2008 that criticized the United States in respect of the death penalty, voting rights and detention policy. ${ }^{164}$

Legal analysis, taken in isolation of other considerations, cannot say whether the costs of an international commitment are merited by its benefits, so to a large degree the concerns expressed in respect of compliance burden and reputational risk are to be addressed by policy-makers, not lawyers. There can be no doubt that participation in a U.N. treaty monitoring body entails compliance costs. And it is not unusual for some participants to use the monitoring bodies as platforms from which to broadcast political views on matters not falling within the bodies' competence. The United States participates in other international bodies that entail these burdens. To form a view as to what burdens participation in the CRPD would entail, the compliance mechanisms of that treaty therefore may be considered and compared against others in which the United States has participated.

\section{(1) CRPD Compliance Mechanisms}

The CRPD establishes two international entities: a Committee on the Rights of Persons with Disabilities (CRPD Article 34) and a Conference of States Parties (CRPD Article 40). ${ }^{165}$

Meetings of the Conference of States Parties are to take place

162 S. EXEC. REP. No. 112-6, supra note 86, at 18.

${ }^{163} \mathrm{Id}$.

${ }^{164}$ Id. This would appear to have been the conclusion reached in Concluding Observations in Respect of the United States, Comm. On the Elimination of Racial Discrimination, 72d Sess., Feb. 18-Mar. 7, 2008, U.N. Doc. CERD/C/USA/CO/6 (2008). See also Groves, supra note 87.

165 On the drafting work, negotiations, and alternative proposals, see Lord \& Stein, supra note 61, at 689, 691-96. For the considerably more expansive proposals for a CRPD monitoring body, which were rejected, see id. at 700-13. Apparently, one factor which led to the adoption of the more modest proposals was that negotiations began in the Ad Hoc Committee rather late, and so little time was afforded for working out the details of the more controversial proposals. Id. at 693-94. 
"biennially or upon the decision of the Conference of States Parties." 166 The purpose of the Conference is "to consider any matter with regard to the implementation of the present Convention.” 167 The provision for a regular meeting to consider "any matter" (i.e., including substantive matters) had not been a standard provision in the human rights treaties, though the earlier human rights treaties provided for regular meetings to elect members to their monitoring bodies ${ }^{168}$ and for meetings upon request of the States Parties to consider proposals for amendments. ${ }^{169}$ Mexico and others had sought to establish a CRPD conference procedure covering a wider scope of activities. ${ }^{170}$

In multilateral treaties, it is by no means unheard of for State conferences to exercise more extensive functions-e.g., under the Antarctic Treaty, the State conference may adopt proposals for new measures in implementation of the agreement. ${ }^{171}$ The exact scope of the work of the Conference of States Parties to the CRPD will depend in some measure on the decisions taken by the Parties in the Conference, ${ }^{172}$ but the functions nevertheless seem to go somewhat further than those provided for under other human rights conventions. ${ }^{173}$ It may be asked whether the conference procedure is aptly termed a compliance mechanism at all. Its chief concern is likely to be policy-setting among the CRPD Parties. Participation in it would

${ }^{166}$ Convention Disabilities, supra note 1 , at art. 40(2).

${ }^{167}$ Id. art. 40(1).

168 See, e.g., ICCPR, art. 30(4), supra note 63; Convention against Torture, art. 17(3), supra note 66, at 199; Convention Migrant Workers, art. 72(4), supra note 69, at 270.

${ }^{169}$ See, e.g., ICCPR, art. 51(1), supra note 63; Convention Against Torture, art. 29(1), supra note 66, at 200; Convention Migrant Workers, art. 90(1), supra note 69, at 273.

${ }^{170}$ Lord \& Stein, supra note 61, at 696 n.36, 707-08. See id. at 707 n.108 especially (setting out details of Mexico's proposal).

171 The Antarctic Treaty of 1959, art. IX, ๆ 1, Dec. 1, 1951, 402 U.N.T.S. 71, 78-80 provides for Antarctic Treaty Consultative Meetings (ATCMs) with competence, inter alia, to "formulat[e] and consider[], and recommend[] to their Governments, measures in furtherance of the principles and objectives of the Treaty” (art. IX, ๆ 1), adopted Dec. 1, 1951, entered into force June 23, 1961, 402 U.N.T.S. 71, 78-80. There is a qualitative difference between the governance structures, where the treaty constitutes a public international organization with its own legal personality and where it provides merely for inter-State meetings, but examples of a range of structures nevertheless may be instanced in this connection; see, e.g., the Whaling Commission under the International Convention for the Regulation of Whaling, arts. III-VI, Dec. 2, 1946, 161 U.N.T.S. 72, 76-82; the Assembly of States Parties under the Rome Statute, supra note 24, art. 112 at 76-77; Plenipotentiary Conference under the International Telecommunications Convention, arts. 6, 53, Oct. 25, 1973, 1209 U.N.T.S. 254, 259, 273.

${ }^{172}$ Lord \& Stein, supra note 61, at 708, 714.

${ }^{173}$ On the innovative aspect of the CRPD Conference, see Trömel, supra note 38, at 135; Lord \& Stein, supra note 61, at 696-97. Cf. International Convention for the Protection of All Persons from Enforced Disappearance, art. 27, supra note 71 (providing for a conference of States Parties "to evaluate the functioning of the Committee"-but this particular provision, it would seem, is limited to the purpose of evaluating whether to transfer the functions of the Committee to another body). 
entail the usual costs associated with a State representative attending a diplomatic conference.

As to the CRPD Committee, this is a monitoring body that adds to the system of U.N. human rights organs, as noted above. ${ }^{174}$ The United States suggested, in observations in the Ad Hoc Committee, that monitoring should take place mostly at a national level. ${ }^{175}$ The United States during drafting opposed establishment of a new monitoring body. ${ }^{176}$ The United States later stated that it was flexible in respect of monitoring, even as it still sought to discourage the establishment of a new treaty organ. According to the U.S. representative in the Ad Hoc Committee, the United States

strongly supported the need for international monitoring, but, in light of the current need for treaty body reform and the specific comments of the High Commissioner on Human Rights, it suggested using existing international monitoring bodies in lieu of the creation of a new, independent monitoring committee. Use of existing monitoring bodies would provide immediate expertise on nondiscrimination, consistency of jurisprudence, efficiency, avoidance of redundancy and cost saving. The existing bodies, such as the Human Rights Commission, already have jurisdiction over many issues in the convention and have dealt specifically with disabilities issues. Moreover, mainstreaming into existing bodies could reinvigorate these bodies. However, the United States emphasized its flexibility on the issue. ${ }^{177}$

The "mainstreaming" approach was not taken. As noted, the Convention, as adopted, includes a monitoring body of its own.

Like the other bodies comprising the U.N. human rights monitoring system, the CRPD Committee receives periodic reports from States Parties as required under the Convention and communicates with States Parties with respect to their obligation to transmit reports. ${ }^{178}$ The independent executive power of the CRPD Committee to issue sanctions against a State for non-

\footnotetext{
${ }^{174}$ See, supra text accompanying footnotes $62-71$.

175 Ad Hoc Comm., 6th sess., supra note 34, Daily summaries, Aug. 9, 2005, Vol. 7, \# 7.

${ }^{176}$ Ad Hoc Comm., 7th sess., supra note 34, Daily summaries, Jan. 27, 2006, Vol. 8, \# 10.

${ }^{177}$ Id., vol. 8, \# 15.

178 Respecting the first sessions of the Committee, see Ron McCallum, The United Nations Convention on the Rights of Persons with Disabilities: Some Reflections, SYDNEY L. SCHOOL RES. PAPER No. 10/30, 2010, available at http://perma.cc/Q4Q5-S5HG. Professor McCallum was elected to the CRPD Committee on Nov. 3, 2008 and served as its Chair in 2010 (effective from Feb. 22, 2010). See Rep. of the Conference of States Parties to the Convention on the Rights of Persons with Disabilities, 1st sess., Oct. 31 \& Nov. 3, 2008, U.N. Doc. CRPD/CSP/2008/4, II 7 (Nov. 3, 2008); Rep. of the Comm. on the Rights of Persons with Disabilities, 2nd sess., Oct. 19-23, 2009, U.N. Doc CRPD/C/2/2, ๆ 15 (Oct. 23, 2009).
} 
compliance with the transmission requirement or for non-compliance with substantive provisions of CRPD is extremely limited. States that become party to the Optional Protocol recognize the competence of the CRPD Committee to "receive and consider communications from or on behalf of individuals or groups of individuals subject to its jurisdiction who claim to be victims of a violation by that State Party of the provisions of the Convention" ${ }^{179}$ The CRPD may issue interim measures against a State Party in instances where "irreparable damage" might occur as a result of a CRPD violation. ${ }^{180}$ The Committee may carry out an inquiry into a State Party's conduct when it has been presented "reliable information indicating grave or systematic violations." 181 Article 6(3) provides that "[a]fter examining the findings of such an inquiry, the Committee shall transmit these findings to the State Party concerned together with any comments and recommendations." ${ }^{182}$ The Committee has no further enforcement power; it is open to States Parties accepting the Optional Protocol to decline to recognize the competence of the Committee to carry out such inquiry and to transmit such findings. ${ }^{183}$ Proposals were made at the drafting stage to establish independent external review procedures, similar to the World Trade Policy Review Body, OECD peer review, IMF thematic targeted approach, or review commissions under the Convention on Nuclear Safety, but none of these were incorporated into the CRPD. ${ }^{184}$

The main potential administrative burden that CRPD might impose thus is contingent. The burden is contingent in particular upon adoption of the Optional Protocol. The CRPD system is not an all-or-nothing package. A State may become party to the Convention and also accept the Optional Protocol, or a State may become party to the Convention and decline to accept the Optional Protocol.

The United States has dealt with similar choices before in its treaty practice. The United States is party to the ICCPR but not party to either ICCPR Optional Protocol. The United States has accepted the ICCPR Article 41 mechanism of State communications. ${ }^{185}$ The United States in this way became party to the ICCPR but chose not to participate in the full scope of ICCPR procedures. It is open to the United States to adopt a similar approach with respect to the CRPD. If the administrative and political burden of the

\footnotetext{
${ }^{179}$ See Optional Protocol, supra note 15, at art. 1(1).

180 See Optional Protocol, supra note 15, at art. 4.

181 See Optional Protocol, supra note 15, at art. 6, ๆף 1, 2.

182 See Optional Protocol, supra note 15, at art. 6(3).

183 See Optional Protocol, supra note 15, at art. 8.

${ }^{184}$ Lord \& Stein, supra note 61, at 704-06.

185“[T] $[$ he United States declares that it accepts the competence of the Human Rights Committee to receive and consider communications under Article 41 in which a State Party claims that another State Party is not fulfilling its obligations under the Covenant.” ICCPR, supra note 63.
} 
communications process under the CRPD Optional Protocol is excessive, then the United States could ratify the Convention and remain a non-party to the Optional Protocol. Insofar as the CRPD might impose a compliance burden, that burden would be readily avoided by selective participation in the Convention régime. In this light, it is doubtful whether the Committee would "impos[e] requirements on the United States and other affluent countries that it does not press on less developed states." ${ }^{186}$ The United States, if it so chose (and it almost inevitably would), would not participate in the Committee mechanism.

Relevant as well in this connection is Professor Curtis Bradley's proposal that the Senate include an understanding confirming the limited authority of the Committee. ${ }^{187}$ If the adopted multilateral text itself did not already make clear that that authority was "limited," such an understanding would remove any doubt.

Apart from each State's right to decline to participate, there are further limitations on the Committee's authority that operate even for States that have become party to the Optional Protocol. Optional Protocol Article 2 is a limiting provision that identifies situations requiring the Committee to reject a communication as inadmissible. These are (as lettered under Article 2): (a) the communication is anonymous; (b) it "constitutes an abuse of the right of submission ... or is incompatible with the ... Convention"; (c) it concerns a matter already examined by the Committee or under examination under "another procedure of international investigation or settlement"; (d) it is made before "[a]ll available domestic remedies have . . . been exhausted"; (e) it is manifestly ill-founded or not sufficiently substantiated; or (f) it concerns facts that occurred before entry into force of the Optional Protocol for the State Party concerned. ${ }^{188}$

In respect of its institutional mechanisms, it would seem that the chief risk in ratifying the CRPD is that other States would raise extraneous political questions in the Committee on the Rights of Persons with Disabilities. This was a point raised by Steven Groves, who referred to practice in some of the other human rights monitoring bodies. ${ }^{189}$ One of the questions mentioned as potentially intruding on committee proceedings is that of the death penalty. ${ }^{190}$ Some observations may be drawn from practice to date in that connection.

\footnotetext{
${ }^{186}$ Convention on the Rights of Persons with Disabilities: Testimony Before the S. Foreign Relations Comm., 113th Cong. (2013) (testimony of Jeremy Rabkin, Professor of Law, George Mason School of Law), available at http://perma.cc/49C3-2KCL.

187 Testimony Before the S. Foreign Relations Comm. Regarding the U.N. Convention on Rights of Persons with Disabilities, 113th Cong. (2013) (testimony of Curtis A. Bradley, William Van Alstyne Professor, Duke Law School), available at http://perma.cc/YNX6JX6U.

${ }^{188} \mathrm{Id}$.

${ }^{189}$ Groves, supra note 87, at 87-88.

190 Sen. DeMint, supra note 86; Groves, supra note 87.
} 


\section{(2) The Death Penalty in the United States as Addressed in Other Human Rights Organs}

Indication was given in the drafting work that certain States Parties are likely to refer to the CRPD in démarches expressing opposition to the death penalty generally and in connection with the death penalty as applied to persons with disabilities specifically. ${ }^{191}$ It is submitted that U.S. ratification of the CRPD would not, however, give critics of the death penalty a persuasive new legal argument. Existing human rights treaties contain provisions expressly and principally concerned with the death penalty. To turn again to the ICCPR, there are the death penalty provisions under Article $6{ }^{192}$ The United States' reservation in respect of the death penalty ${ }^{193}$ drew objection from a number of States. ${ }^{194}$ The Human Rights Committee, in its observations on the United States' periodic reports submitted under ICCPR Article 40, has criticized the United States in respect of the death penalty. For example, in 2006 the Committee said that it

regrets that the State party does not indicate that it has taken any steps to review federal and state legislation with a view to assessing whether offences carrying the death penalty are restricted to the most serious crimes, and that, despite its previous concluding observations, the State party has extended the number of offences for which the death penalty is applicable. ${ }^{195}$

Members of the Committee in the course of its proceedings from time to time also have used the Committee as a platform to express individual criticisms of the death penalty as applied in the United States. For example, at the 100th session of the Committee, Robert Badinter, the former President of the Conseil Constitutionnel of France and a prominent opponent of the death penalty, regretted the continued implementation of the death penalty in certain U.S. states. ${ }^{196}$ As an initial point, it may be asked whether statements such as Mr. Badinter's or even official communications such as the

191 See Working Group, supra note 42, Daily Summary, Vol. 3, \# 7, Jan. 13, 2004, at 17 (observation by Ireland).

192 ICCPR, supra note 63.

${ }^{193} \mathrm{Id}$.

${ }^{194}$ Id. Objections: Belgium, Oct. 5, 1993; Denmark, Oct. 1, 1993; Finland, Sept. 28, 1993; France, Oct. 4, 1993; Germany, Sept. 29, 1993; Italy, Oct. 5, 1993; Netherlands, Sept. 28, 1993; Norway, Oct. 4, 1993; Portugal, Oct. 5, 1993; Spain, Oct. 5, 1993; Sweden, June 18, 1993.

195 Human Rights Comm., Consideration of Report Submitted by the United States of America, ๆ 29 , U.N. Doc. CCPR/C/USA/CO/3/REV.1 (Dec. 18, 2006).

${ }^{196}$ U.N. Human Rights Comm., 100th Sess., 2771st mtg., at 17, U.N. Doc. CCPR/C/SR.2771 (Oct. 29, 2010). 
Committee's observations in 2006 are a valid ground in themselves for the United States to decline to participate in the international human rights apparatus. These are not formal determinations supported by an enforcement mechanism. Even within their (limited) bounds, they are purely hortatory, a far cry from injunctions against the sovereign prerogatives of a superpower. Critical remarks in an international organ well may touch a sensitive nerve in national politics and thus influence a State's decision whether, and to what extent, to participate in its proceedings, but a balanced view should be taken in respect of the legal effects of such practice. The legal effects, in the balanced view, are modest, to the extent that they can be discerned at all.

The further point relates to the CRPD specifically. It is difficult to see how participation in the CRPD would add materially to the legal bases for international organs or their members to criticize the United States in respect of the death penalty. It would be more natural for death penalty opponents to refer to provisions such as ICCPR Article 6 (as they already do) than to rely on an unrelated treaty for merely inferential support. Ratification of the CRPD would not concede new points to death penalty opponents. The CRPD is not the logical text on which to base a renewed attack against the death penalty. It well may be that death penalty opponents would refer to the CRPD during the proceedings of the Committee, but this would be a marginal practice in the international human rights framework.

\section{(3) International Assistance Under CRPD Article 32}

A final matter regarding international compliance may be touched upon. In the Working Group, which produced the draft convention text, participants expressed concern that the draft might imply an international obligation to engage in international cooperation. The members "considered that the issue should not be interpreted as imposing obligations beyond any other existing model of international cooperation.”197 Under general international law, no State is obliged to provide development assistance or to engage in international cooperation. ${ }^{198}$ An exception to this presumption

197 Working Group, supra note 42, at Annex 2, ๆ 5 (summary of discussions).

198 The freedom of States to control their international relations is axiomatic; see Military and Paramilitary Activities in and against Nicaragua (Nicar. v. U.S.), Merits, Judgment, 1986 I.C.J. 14, I 205 (June 27). Writers who assert that an international obligation exists to provide development assistance nevertheless concede that this is not highly specific; see, e.g., URFAN Khaliq, Ethical Dimensions of the Foreign Policy of the European Union: A Legal APPRAISAL 69 (2008). To the extent that international statements have been adopted about aid to less developed States, these have been hortatory only—sometimes called "soft law" (which really means "not law"). The clear language of obligation in treaties, by contrast, has not established an obligation to render aid; see, e.g., Michael Wabwile, Re-Examining States' External Obligations to Implement Economic and Social Rights of Children, 22 CAN. J.L. \& JuR. 407, 424 (2009). As to the meaning of “soft law," see W. Michael Reisman, Soft Law and Law Jobs, 2 J. INT’L DisP. SETTLEMENT 25, 25-26 (2011). 
could be established by the explicit consent of States parties to an international agreement not by inference or other secondary method of interpretation. While States Parties under CRPD Article 32 (International cooperation) “ . . . will undertake appropriate and effective measures," the clear way to have denoted an obligation would have been to say precisely what those measures shall be. ${ }^{199}$ The provision as adopted neither says what the measures are, nor that they must be undertaken at all. It merely gives examples of measures that could be taken-“"s]uch measures could include . . . "200 Moreover, Article 32 contains no definition of "international cooperation." Its first sentence, in paragraph 1, says that "States Parties recognize the importance of international cooperation and its promotion ... . "201 This is a classic statement of principle, drawing attention to a policy goal but open-ended as to how the goal might be achieved and setting down no obligation, either of conduct or of result. Under the CRPD, international cooperation remains elective, not obligatory.

Article 32 nevertheless may have an effect on the modalities of international cooperation. Subsection (a) of Article 32 identifies the following as a step that States could take: "[e]nsuring that international cooperation, including international development programmes, is inclusive of and accessible to persons with disabilities." ${ }^{202}$ Though not obliging States to establish new international aid programmes, Article 32 thus encourages States to make their aid programmes accessible to persons with disabilities. It has been argued that this step is overdue, for example in the U.S. Agency for International Development (USAID). ${ }^{203}$

The main obligation established by the Convention is for each Party to adopt national legislation (statutory and regulatory) to effectuate the rules, standards, and principles contained in the Convention. The main burden on a State Party thus likely would arise from that obligation. The effects of the CRPD on the existing legal system now may be considered.

\section{Effect of the CRPD's Provisions on the Existing Legal System}

According to CRPD Article 4, paragraph 1(a), "States Parties undertake ... [t t]o adopt all appropriate legislative, administrative and other measures

199 Convention Disabilities, supra note 1.

200 Convention Disabilities, supra note 1.

${ }^{201}$ Convention Disabilities, supra note 1.(emphasis added).

202 Convention Disabilities, supra note 1.

203 Michael Stein, Mainstreaming and Accountability: (Really) Including Persons with Disabilities in Development Aid and Humanitarian Relief Programming, 31 NoRDIC J. HuM. RTS. 292 (2013). See also NAT'L COUNCIL ON DisABILITY, TOWARD THE FULL INCLUSION OF People with Disabilities: Examining the Accessibility of Overseas Facilities and Programs Funded by the United States 1, 94 (2013). 
for the implementation of the rights recognized in the present Convention.”204 Turning the provisions of CRPD into effective legislation at national level is the main substantive obligation of the States Parties. The Working Group recognized that "implementation of the Convention will be primarily a national responsibility.",205

Four objections may be identified in respect of the anticipated effect of the CRPD at municipal level: (i) the standards the Convention aims to implement at the municipal level have already been met or exceeded in the United States and so the Convention serves no purpose; ${ }^{206}$ (ii) the standards in the Convention are less exacting than those in force in the United States and therefore its application will erode the legal protections available to persons with disabilities in the United States; ${ }^{207}$ (iii) U.S. ratification of the Convention would expedite the formation of customary international law rules in respect of persons with disabilities and those rules, in turn, would enter U.S. law when applied by U.S. courts; ${ }^{208}$ and (iv) the Convention would create "no extraterritorial rights . . . for American travellers, businessmen, servicemembers, or veterans." 209

Each of these objections may be addressed in turn. Some, as will become clear, concern the existing international legal system as much or more than U.S. national law.

\section{(1) U.S. Legislation as Already Meeting CRPD Obligations}

The advocates and opponents of the CRPD in the United States were largely in agreement that U.S. law already embodies standards that meet or exceed those adopted in the Convention. Steven Groves (in opposition) said that that the Convention "merely makes an international commitment to continue the status quo here in the United States." 210 The President of the

${ }^{204}$ Convention Disabilities, supra note 1, at 73-74.

205 Working Group, supra note 42, (summary of discussions). As to the fraught relation between treaty obligations and their implementation at the municipal level in the United States, see Laura Moranchek Hussain, Enforcing the Treaty Rights of Aliens, 117 YALE L.J. 680, 721 (2008); Nicholas Quinn Rosenkranz, Executing the Treaty Power, 118 HaRv. L. Rev. 1867, 1892 (2005). See also Written Observations of the United States of America on the Application for Interpretation of the Judgment of 31 March 2004 in the Case Concerning Avena and Other Mexican Nationals (Mexico v. United States of America), Aug. 29, 2008, at 4-9, ๆๆ 9-21 (relating the unsuccessful efforts of multiple officers of the federal government to secure an avenue for the Mexican nationals to obtain review in U.S. state courts of their claims under the Vienna Convention on Consular Relations). To an extent having anticipated the contemporary resurgence of the problem, see Edward T. Swaine, Does Federalism Constrain the Treaty Power?, 103 Colum. L. REV. 403, 418 (2003).

${ }^{206}$ Groves, supra note 87, at 87.

207 See Worsnip, supra note 81.

208158 Cong. REC. S7369 (daily ed. Dec. 4, 2012) (statement of Sen. Lee).

${ }^{209}$ Farris, supra note 88, at 82.

${ }^{210}$ Groves, supra note 86, at 90 . 
United States, in transmitting the Convention to the Senate and recommending its advice and consent to ratification, said, "the strong guarantees of non-discrimination and equality of access and opportunity for persons with disabilities in existing U.S. law are consistent with and sufficient to implement the requirements of the Convention as it would be ratified by the United States."211

It is beyond the scope of the present article to review the laws of the United States in the area of the rights of disabled persons. ${ }^{212}$ Such a review would be necessary if the assertion were to be tested that the United States satisfies the requirements of the CRPD in respect of municipal legislation. As the President, in endorsing the Convention, and one of the chief experts speaking against it, concurred, it is not necessary for present purposes to settle the point. ${ }^{213}$

An observation nevertheless may be made in connection with the objection that U.S. law already meets the Convention standard. Implicit in the legal objection is an objection of policy: the United States (it follows from the objection) should not, as a matter of policy, adopt new international instruments, unless these have an impact on U.S. law. But that would be a position at stark variance with the opponents' clearly expressed position (also a position of policy) that the United States should not subject itself to international rules that affect its municipal law. Dr. Farris in particular objected that "such treaties [are] a dramatic loss of American freedom in favor of coercive international socialism." ${ }^{214}$ It may be that a foolish consistency is the hobgoblin of little minds, ${ }^{215}$ but if the United States adopted neither treaties that require changes to U.S. law nor treaties that leave U.S. law alone, then nary a ghost of United States treaty practice would remain. In any event, it was not to change the U.S. legislative landscape that the United States considered becoming a party to the CRPD; it was, instead, to promote the policy goal of improving the treatment of persons with disabilities, including Americans, in the territory of other States Parties to the Convention. ${ }^{216}$ As will be suggested in the next section, the Convention indeed has legal effects that would promote that policy goal.

${ }^{211}$ Letter of TransmitTal, supra note 8, at 3. Accord. S. EXec. ReP. No. 112-6, supra note 86, at 45 (testimony of Ms. Eve Hill, Senior Counsellor to the Assistant Attorney General for Civil Rights).

212 For in-depth treatment, see Peter Blanck et AL., Disability Civil Rights LaW AND Policy: CASES AND MATERIALs (2d ed., 2009).

${ }^{213}$ Harold Hongju Koh, Remarks: Twenty-First Century International Lawmaking, 101 GEO. L.J. 725, 730 (2013); see also John R. Cook, Contemporary Practice of the United States Relating to International Law, 107 AM. J. INT'L L. 208, 209 (2013) (observing the U.S. origins of the substantive rules in the CRPD).

${ }^{214}$ Farris, supra note 88, at 89.

${ }^{215}$ Ralph Waldo Emerson, Self-Reliance, Essays: First Series 51, 64 (David McKay ed., 1888) (1841).

${ }^{216}$ LeTter of TransmitTAL, supra note 8, at 3. 
It should be noted here that Dr. Michael Farris differed from the other opponents of ratification on the question of U.S. law. It was Dr. Farris's view that " $[t]$ he changes to American law that will be required to comply with the provisions of this treaty are profound and utterly unacceptable.”217 Dr. Farris was principally concerned with what he believed Article 7 of the Convention requires in respect of parental discretion over the schooling of children, a matter addressed in Part IV(E) below. Former U.S. Attorney General and U.N. Under-Secretary General Dick Thornburgh's view is closer to the mark: "the Disabilities Treaty will require no change to U.S. federal or state law and will have no impact on the federal budget." ${ }^{218}$

\section{(2) The Putative Risk of the CRPD Eroding U.S. Disabilities Legislation}

Concerns were expressed, at the time of its entry into force, that the rules and standards set out in the CRPD furnish less protection to persons with disabilities than U.S. law and, thus, that the CRPD might be to the disadvantage of persons with disabilities in the United States. It was reported, for example, that U.S. officials believed the CRPD to be "weaker than the U.S. Americans with Disabilities Act of 1991 and therefore could complicate enforcement of that law." 219 Senator Lee, during the Senate debate concerning the Convention, said that the Senate had "not adequately investigated how this standard will affect domestic U.S. Federal and State law."220 Senator Sessions said that ratification would lead to "hypocritical meddlers complicating our internal disability efforts, as well as our internal social and health policies." ${ }^{221}$ The concern here seems to have been that the CRPD would impel a flight to the bottom or search for a lowest common denominator and, thus, erode established national legal rules and standards.

In practice, as a general matter of treaty interpretation, it is unlikely that a treaty will erode existing national rights protections, where the treaty is clear that its rules, standards, and principles constitute a minimum, and not an upper limit. The CRPD is clear in this way. It sets out a minimum standard, not a limit preventing States from adopting and maintaining national

\footnotetext{
${ }^{217}$ Farris, supra note 88, at 81.

${ }^{218}$ Testimony Before the S. Foreign Relations Comm. Respecting the Convention on the Rights of Persons with Disabilities, at 9, 113th Cong. (2013) (testimony of Richard Thornburgh, former Att'y Gen. and Under-Sec'y-Gen. of the United Nations).

${ }^{219}$ Worsnip, supra note 81. The Worsnip article did not name the U.S. officials to whom it attributed the observation. Cf. S. EXEC. REP. No. 112-6, supra note 86, at 18 (minority views expressing concern over scrutiny by "a committee of representatives from countries that have lower standards for the disabled than our own”); Groves, supra note 87, at 93 (describing U.S. participation in the CRPD, in light of “America's leadership on disability rights," as "superfluous at best").

220158 CONG. REC. S7369, supra note 208 (statement of Sen. Lee).

221158 Cong. REC. S7373 (daily ed. Dec. 4, 2012) (statement of Sen. Sessions).
} 
legislation and institutions that exceed the standard. States in the drafting work were clear on this. ${ }^{222}$ The point, moreover, was incorporated into a general saving provision. Article 4, paragraph 4, says as follows:

Nothing in the present Convention shall affect any provisions which are more conducive to the realization of the rights of persons with disabilities and which may be contained in the law of a State Party or international law in force for that State. There shall be no restriction upon or derogation from any of the human rights and fundamental freedoms recognized or existing in any State Party to the present Convention pursuant to law, conventions, regulation or custom on the pretext that the present Convention does not recognize such rights or freedoms or that it recognizes them to a lesser extent. ${ }^{223}$

This provision should remove any doubt. The Convention does not create a license to ignore or derogate the rights of persons with disabilities. To be sure, CRPD adopts the expression "reasonable accommodation."224 The modifier "reasonable" may entail testing the effective capacity of a particular person or entity to provide for the needs of persons with disabilities. The provisions referring to "reasonable accommodation," however, have to be read in conjunction with the saving provision, Article 4, paragraph 4 . The saving provision operates upon all other provisions in the instrument: the opening clause-“[n]othing in the present Convention"makes clear that no provision escapes the saving effect. ${ }^{225}$ Therefore, even assuming that litigants could apply the Convention directly in U.S. courts (which they could not), it is difficult to see how any given provision of the CRPD could be used to undermine existing U.S. legal standards for the treatment of persons with disabilities.

\section{(3) Possible Effect of U.S. Ratification of the CRPD on Customary International Law}

Senator Mike Lee (Utah), during the Senate debate respecting the CPRD, set out a more nuanced position as to the legal effect the Convention might have on U.S. legislation. Rather than reiterate the view that it would

\footnotetext{
222 The concern also was expressed in the drafting work that the CRPD not be interpreted to reduce the level of protection already extended to disabled persons by way of existing international agreements (e.g., ICESCR). See Working Group, supra note 42, Daily Summary, Vol. 3, \# 1, at 16, Jan. 5, 2004 (observation of Germany).

${ }^{223}$ Convention Disabilities, supra note 1, art. 4(4).

${ }^{224}$ Id., arts. 2, 6(3), 14(2), 27(1)(i), 24(5), 24(2)(c).

${ }^{225} \mathrm{Id}$. (emphasis added).
} 
undermine existing U.S. statutory provisions directly, Senator Lee said that the CRPD would affect the development of customary international law, which, in turn, would be applied through U.S. courts and thus affect U.S. law. Senator Lee's position was as follows:

[W]henever a body of law, whether embodied in U.N. convention or otherwise, becomes part of the corpus of customary international law, that often makes its way into U.S. judicial opinions. Is it direct? No. Does it directly undo any statute? No. But that doesn't mean it has no effect. If it had no effect we would not be here debating it today. It is the type of effect we worry about.

[Senator Kerry] and I see things differently as far as what type of effect it might have. But that is not to say it has no effect. We should not be ratifying a treaty that we think might offset U.S. law as it exists now. We believe this could have that impact. Exactly where that is going to come up, I cannot prove to the Senator where that is going to happen. But it does have some impact, and when we ratify a treaty we make it the law of the land. ${ }^{226}$

Senator Lee's position, that the CRPD by way of customary international law "might offset U.S. law as it exists now," led to an exchange with Senator Kerry on the process of the formation of customary international law. ${ }^{227}$ Senator Kerry said, "a treaty does not become customary international law just because the United States or another country ratifies it." 228 Senator Lee replied, “[i]t doesn't become the law of the land just because it is in the treaty." ${ }^{229}$ But he went on to say, "it often does. Its entry into customary international law can become facilitated by the U.S. ratification of it." 230 Assuming that Senator Lee meant "[i]t doesn't become [customary international law] just because it is in the treaty,"231 he concurred with Senator Kerry on the relation between treaties and customary international law. To the extent that both Senators understood that it does not necessarily make a rule part of customary international law that it is contained in a treaty, they were in agreement. As to their difference, this concerned how precisely a rule enters customary international law. Their airing of the difference is

\footnotetext{
226158 CoNG. REC. S7369, supra note 208 (statement of Sen. Lee).

${ }^{227} \mathrm{Id}$.

${ }^{228}$ Id. (statement of Sen. Kerry).

${ }^{229} \mathrm{Id}$. (statement of Sen. Lee).

${ }^{230} \mathrm{Id}$.

231 This is the sensible interpretation, in light of the context of the Senator's statement and in light of Article VI, clause 2 of the U.S. Constitution.
} 
arguably one of the more sophisticated exchanges to have taken place on the U.S. Senate floor on the topic of customary international law. The substance of the exchange merits consideration.

International claims practice is a useful starting point in considering the relation between treaty law and customary international law. It is not unusual in international claims practice for the number of States that accede to a multilateral instrument to be adduced as evidence that the rules in the instrument (or some of them) belong to customary international law. ${ }^{232}$ To say that "[i]ts entry into customary international law can become facilitated" when a rule is found in treaty practice is right. ${ }^{233}$ The International Court has said as much, ${ }^{234}$ and the United States has argued the point before its own courts. ${ }^{235}$ However, the relationship between customary international law and treaties is by no means mechanistic. There is no rule to indicate that $X$ number of States acceding to a treaty suffices to identify the rules in the treaty as rules of customary international law, but $X$ minus 1 number of States acceding to the treaty does not. The absence of a simple equation is not a license to ignore the practice, ${ }^{236}$ but it suggests the difficulty in defining the effects of a cumulative practice (including treaty practice) on rule formation. The Special Rapporteur of the International Law Commission (ILC) on the topic of the formation and evidence of customary international law has identified the

${ }^{232}$ See, e.g., Pulp Mills on the River Uruguay (Arg. v. Uru.), Counter-Memorial, Uruguay, at 53, n.75 (July 20, 2007) (referring to Principles 21 and 22 of the Stockholm Declaration and the 112-0 vote in favour of the Declaration). Cf. Arrest Warrant of April 11, 2000 (Dem. Rep. of Congo v. Belg.), Counter-Memorial, Kingdom of Belgium, at 134, \ 3.5.19 (Sept. 28, 2001) (observing that six of the seven participants in the deliberations leading to adoption of the Treaty of Versailles believed that the international law character of the alleged crimes of the German Kaiser (and not the international law character of the proposed criminal tribunal) formed the basis for waiver of immunity). The method also is seen in national judicial practice. See, e.g., Sarei v. Rio Tinto, PLC, 671 F.3d 736, 764 (9th Cir. 2011) (Schroeder, Cir. J., referring to the 180 States Parties to the Geneva Conventions as evidence of the customary international law rule).

${ }^{233} \mathrm{Id}$.

234 See, e.g., Continental Shelf (Libyan Arab Jamahiriya/Malta), Judgment, 1985 I.C.J. 13, ๆ 27 (June 3) ("[M]ultilateral conventions may have an important role to play in recording and defining rules deriving from custom, or indeed in developing them.” (emphasis added)). See Jurisdictional Immunities of the State (Ger. v. It.: Greece intervening), Judgment, 2012 I.C.J. 99, I 55 (Feb. 3); Dispute Regarding Navigational and Related Rights (Costa Rica v. Nicar.), Judgment, 2009 I.C.J. 213, I 26; Questions Relating to the Obligation to Prosecute or Extradite (Belg. v. Sen.), Judgment, 2012 I.C.J. 422, 999 (July 20).

${ }^{235}$ U.S. v. Bellaizac-Hurtado, 700 F.3d 1245, 1254-55 (11th Cir. 2012) (seeking to establish (in the event, unsuccessfully) that an international prohibition against drug trafficking is a rule of customary international, the United States argued that widespread ratification of the 1988 United Nations Convention Against Illicit Traffic in Narcotic Drugs and Psychotropic Substances established the rule). Contra Sarei v. Rio Tinto, PLC, 671 F.3d 736, 764 (9th Cir. 2011).

${ }^{236}$ See Jurisdictional Immunities of the State, (Ger. v. It.), Memorial of the Federal Republic of Germany, at 21, ๆ 31 (June 12, 2009). 
relationship between treaties and customary international law as "an important aspect of the topic"; ${ }^{237}$ and the proposal to examine "the density of practice" ${ }^{238}$ suggests the relevance as well of accumulation, e.g., of multiple accessions to a treaty.

So it is certainly the case that U.S. ratification of a treaty can "facilitate[ ... ]" the process of customary international law formation. But it is hardly the case that U.S. ratification alone completes the process. U.S. courts have been clear on this. ${ }^{239}$ U.S. courts, moreover, have been clear that even a very large number of accessions does not necessarily in itself identify a rule. The U.S. Court of Appeals (Second Circuit), in Kiobel v. Royal Dutch Petroleum Co., said
Although all treaties ratified by more than one State provide some evidence of the custom and practice of nations, "a treaty will only constitute sufficient proof of a norm of customary international law if an overwhelming majority of States have ratified the treaty, and those States uniformly and consistently act in accordance with its principles." 240

The Court of Appeals's analysis is in accordance with the general understanding. By acceding to a treaty, States acknowledge the obligatory character of the propositions it contains, but accession alone does not amount to the requisite practice. Customary international law is both practice and opinio juris, and so even an unambiguous statement accepting the obligatory character of a rule does not suffice to constitute customary international law without the practice. A treaty rule is certainly obligatory - for the treaty parties. It does not in itself constitute customary international law. The analysis in Kiobel is broadly consistent with other judgments of the Circuits of the U.S. Court of Appeals in respect of the definition of customary international law. Six (of the thirteen) Circuits follow the Restatement (Third) of Foreign Relations Law, which defines customary international law as a "general and consistent practice of states followed by them from a sense of legal obligation.”241

\footnotetext{
${ }^{237}$ Michael Wood, Special Rapporteur, Formation and Evidence of Customary International Law, Int'l Law Comm'n, 64th Sess., ๆ 14, U.N. Doc. A/CN.4/653 (May 30, 2012); see also Rep. of the Int'l Law Comm'n, ๆ 9, 63d Sess., Apr. 26-June 3, July 4-Aug. 12, U.N. Doc. A/66/10; GAOR 66th Sess., Supp. No. 10 (2011).

${ }^{238}$ Rep. of the Int'l Law Comm'n, supra note 237, at 9 8(vi).

239 See, e.g., Bellaizac-Hurtado, 700 F.3d at 1254-55.

${ }^{240}$ Kiobel v. Royal Dutch Petroleum Co., 621 F.3d 111, 113 (2d Cir. 2010), aff'd, 133 S. Ct. 1659 (2013) (quoting Flores v. S. Peru Copper Corp., 414 F.3d 233, 256 (2d Cir. 2003)). Cf. Kiobel, 621 F.3d at 138.

241 Restatement (ThiRd) OF Foreign Relations § 102(2) (1987). For the Eleventh Circuit position and citations to five other circuits, see Bellaizac-Hurtado, 700 F.3d at 1251-52.
} 
In international claims practice as well, tribunals have cautioned that the existence of a treaty rule does not in itself establish the existence of a customary international law rule. Considering lump sum settlement agreements, the Iran-United States Claims Tribunal in the interlocutory award in SEDCO observed that such agreements "can be so greatly inspired by non-judicial considerations ... that it is extremely difficult to draw from them conclusions as to opinio juris ..."242 The ICJ and other tribunals have made a similar point. ${ }^{243}$ It is questionable whether a given instance of treaty practice demonstrates the emergence of a customary rule. There are situations, such as the U.S. and Canadian adoption of NAFTA, in which the States parties declared, in terms, that a treaty standard (in that case, a minimum standard of treatment entailed under NAFTA Article 1105(1)) is "based on long-standing principles of customary international law." 244 But here the States in question explicitly stated their view that the treaty reflected or was based on a standard under customary international law. There was no need to look further to establish the existence of opinio juris or of practice. ${ }^{245}$ Conversely, there is no need for the United States, if it ratifies the CRPD, to declare that this instrument reflects customary international law. If the United States does not believe that it does, then by refraining from saying so- or, even more so, by saying that it does not - the United States will avoid the inference that adoption of the CRPD has established or reflects a general law on disability rights.

Senator Lee suggested that U.S. treaty practice is highly influential in the formation of customary international law, which no doubt it is. But to say the rule "often does" take form as a rule of customary international law "just because it is in the treaty" is to say (i) that the inclusion of the rule in the treaty suffices and (ii) that customary international law often takes form in this way. ${ }^{246}$ Senator Lee’s position differs from Senator Kerry’s, and from

242 SEDCO Inc. v. National Iranian Oil Company, Interlocutory Award of March 27, 1986, 10 Iran-U.S. Cl. Trib. Rep. 180, 185 (1986) (Mangård, Chairman; Brower \& Ansari, Members); see also id. at 202 (seperate opinion of Member Brower, concurring on this point).

${ }^{243}$ See, e.g., Barcelona Traction (Belg. v. Spain), Judgment, 1970 I.C.J 3, I 40 (Feb 5); Kuwait v. Aminoil, Final Award of March 24, 1982, 21 I.L.M. 976, at 1036, ๆ 156-57 (Reuter, President; Sultan \& Fitzmaurice, Arbitrators); EnCana Corporation v. Republic of Ecuador, Award of Feb. 3, 2006, 12 ICSID Rep. 400, 465-66, ๆ 147 (Crawford, President; Grigera Naón \& Barrera Sweeney, Members).

${ }^{244}$ Mondev International Ltd. v. United States of America, ICSID Case No. ARB(AF)/99/2, Award of Oct. 11, 2002, 6 ICSID Rep. 181, 220-21, ๆ 111 (Stephen, President; Crawford \& Schwebel, Members) (quoting Canada, Department of External Affairs, North American Free Trade Agreement, Canadian Statement on Implementation, CAN. GAz., Jan. 1, 1994, 68, 149; S. TREATY Doc. No. 103-15, at ix (1993) (transmittal statement to U.S. Senate in respect of United States-Ecuador BIT).

245 Though in Mondev there was a need to identify the substantive content of the customary rule; see Mondev, 6 ICSID Rep. 181, at 221, 9113.

246158 Cong. Rec. 57364, supra note 208 (statement of Sen. Lee). 
the general and the American understanding, insofar as it suggests that acts of accession to treaties are in themselves conclusive as to the formation of customary international law rules and that customary international law rules take form through treaty accession often. The first proposition here does not follow the existing position under U.S. law as set out in the Court of Appeals judgments. As seen above, the courts are clear that the inclusion of the rule in a treaty does not alone necessarily establish the rule as a rule of customary international law.

And it can be seen, from the U.S. decisions and from practice more generally, that customary international law rules do not, at least in the usual course of international relations, take form very rapidly and, in any event, not with as high a frequency as accessions to treaties. Across the range of treaties open for signature and ratification, the number of ratifications in any given year is very considerable; the number of new customary international law rules to emerge, much less so. This is visible from U.S. judicial practice. U.S. courts have understood that new rules do not frequently come into being. ${ }^{247}$ International judges have understood this as well. In Navigational and Related Rights, Judge ad hoc Guillaume observed that many treaties address navigational rights on rivers, but on the same matter the customary international law rules are scant. ${ }^{248}$ The Court in Ahmadou Sadio Diallo observed that the extensive treaty practice in the matter of investment protection has not changed the customary law of diplomatic protection. ${ }^{249} \mathrm{In}$ Arrest Warrant, the Court concluded that multiple international instruments establishing criminal jurisdiction over State officials have not created a customary international law rule suspending the immunity of State officials before national courts. ${ }^{250}$

Accession to a treaty may promote the emergence of rules in the treaty as rules of customary international law. Accession, however, seldom has led to that emergence instantly; the process usually is very slow; ${ }^{251}$ seldom has a new rule emerged by the accession of one State alone. Lord Bingham of Cornhill put the matter categorically: "one swallow does not make a rule of international law." ${ }^{252}$ Whatever comparison might be drawn between the weight of U.S. practice and that of a swallow, the general point remains.

\footnotetext{
${ }^{247}$ See, e.g., U.S. v. Bellaizac-Hurtado, 700 F.3d 1245, 1254-57 (11th Cir. 2012).

248 Navigational and Related Rights, supra at $\mathbb{}$ I 3.

${ }^{249}$ Ahmadou Sadio Diallo (Guinea v. Dem. Rep. Congo), Preliminary Objections, Judgment, 2007 I.C.J. 582, ๆ 90 (May 24).

${ }^{250}$ Arrest Warrant of 11 April 2000 (Dem. Rep. of Congo v. Belg.), Judgment, 2002 I.C.J. Rep. 3, ๆ 58 (Feb. 14).

${ }^{251}$ See Jurisdictional Immunities of the State (Ger. v. It.: Greece intervening), Judgment, 2012 I.C.J. 99, ๆ 62 (Feb. 3).

252 Jones v. Ministry of Interior Al-Mamlaka Al-Arabiya AS Sandiya (the Kingdom of Saudi-Arabia), [2006] UKHL 26 (H.L.) [ף 22] (appeal taken from Eng.).
} 


\section{(4) Legal Consequences of the CRPD in Respect of the Treatment of Americans Abroad}

A further set of objections was that the CRPD would do nothing to improve conditions for Americans with disabilities. Among these objections, one concerned in particular the effects of the CRPD outside the United States. More precisely, the objection was that the CRPD would have no effect at all outside the United States.

According to Dr. Farris, testifying to the Senate Committee on Foreign Relations in respect of ratification of the CRPD, the Convention would create "absolutely no rights for Americans with disabilities when they travel abroad ... [i]f the United States becomes party to a treaty, all of the legal consequences which flow from this act of ratification will be limited to the territory of the United States.”253

This conclusion entails a very narrow understanding of the "legal consequences" a treaty may produce. The CRPD establishes a variety of obligations on its parties, among them-indeed, chief among themobligations to bring national legislation up to a standard set out in the Convention. As a matter of international obligation, the "legal consequences" are hardly "limited to the territory" of one State, for the obligations under the CRPD to meet the standards identified therein are not restricted to one State Party. All States Parties must meet the standards. To fulfill their obligations under the CRPD, States Parties that have not done so already will adopt and implement legislation that affords practical benefits to persons with disabilities. It has been noted that the "dearth of appropriate disability law . . . at the national level" is endemic. ${ }^{254}$ It is hard to see how the benefits of appropriate disabilities laws, once implemented, like physical infrastructure designed to provide access to persons with disabilities, would affect only the nationals of that State Party. An American with a disability, present in the State acting in accordance with the Convention, would be able to take advantage of the benefits as well. True, whether or not the American in the other State has a right of action against that State for non-compliance with the Convention is a matter for the law of the State; a municipal cause of action is not a guarantee under the CRPD. But this is a matter of the municipal procedures - not a matter of "all of the legal consequences which flow from ... ratification." 255

253 S. EXEC. REP. No. 112-6, supra note 86, at 80; see also S. EXEC. REP. No. 113-12, at 73 (2014). Susan Yoshihara, making a similar point in testifying on November 5, 2013, that "American ratification of the treaty will not help disabled Americans, here or abroad." Id.

${ }^{254}$ Lord \& Stein, supra note 61, at 709, 711-12 n.126; see also Theresia Degener \& Gerard Quinn, A Survey of International, Comparative and Regional Disability Law Reform, in Disability Rights Law And Policy: International and National Perspectives 3 (Mary Lou Breslin \& Silvia Yee, eds., 2002).

255 S. Exec. Rep. No. 112-6, supra note 86, at 80. 
Such a narrow understanding of the legal effects of the CRPD ignores that international law is still centrally concerned with obligations between States. The objectors concern themselves with the quintessentially modern development under international law of obligations owed by one State to the individuals under its jurisdiction but forget the basic proposition that international law concerns the obligations States owe to one another. It is incorrect to say that the legal effects of the Convention are limited to the territory of the United States, first of all, because every State Party assumes obligations under the Convention in respect of the laws in force in its territory. Any given State Party might or might not operationalize its obligations by allowing private litigants access to its courts to enforce the Convention rules. But the obligations remain; they do not disappear simply because, in one court system, private litigants cannot enforce them.

National court proceedings are not the only-and, historically, certainly not the main-mechanism through which States have been held to account for breaches of treaty rules. The traditional mechanism, diplomatic protection, though now private parties are far more likely to proceed directly against a State under treaty-based mechanisms, remains available. ${ }^{256}$ And though diplomatic protection, from the procedural standpoint, may be a residue of an earlier phase of international law, the scope of the substantive rules States may apply through diplomatic protection has been dynamic. As the International Court noted the Diallo case,

Owing to the substantive development of international law over recent decades in respect of the rights it accords to individuals, the scope ratione materiae of diplomatic protection, originally limited to alleged violations of the minimum standard of treatment of aliens, has subsequently widened to include, inter alia, internationally guaranteed human rights. ${ }^{257}$

Diplomatic protection would be available to the United States in response to the conduct of other States Parties to the CRPD, if their conduct were to have a negative impact on a U.S. national.

A breach by a State Party entails legal consequences-namely, international responsibility for the breach. In respect of the CRPD and of treaties generally, a breach attributable to a State under international law entails legal consequences under the rules of State responsibility: "[e]very internationally wrongful act of a State entails the international responsibility

256 See Ben Juratowitch, Diplomatic Protection of Shareholders, 81 BRIT. Y.B. INT’L L. 281 (2010).

${ }^{257}$ Ahmadou Sadio Diallo (Guinea v. Dem. Rep. Congo), Preliminary Objections, Judgment, 2007 I.C.J. 582, ๆ 39 (May 24). 
of that State."258 A multilateral instrument like the CRPD, though the main intention behind it is to address how each State Party treats individuals subject to its jurisdiction, creates a web of legal relations among the States Parties, each obliged to the other to act in accordance with the instrument. A breach by one entails legal consequences opposable against it by the others (or, where the rules are not of erga omnes character, at least by those the breach directly affects). ${ }^{259}$ It is, then, further incorrect to say that the legal consequences of the CRPD would be limited to the territory of one State. International responsibility, which results from the breach of obligation by any State, is a legal consequence at the international level.

To consider a hypothetical example, an American armed forces veteran, confined to a wheelchair because of injuries sustained in the line of duty, visits the territory of CRPD State Party A and, on the same trip, CRPD State Party B. State Party A, since acceding to the Convention, has acted fully in accordance with the Convention. Its provisions for persons with disabilities now meet the international standard. For example, transportation facilities in State Party A have been adapted in accordance with CRPD Article 9, paragraph 1(a), and appropriate measures also have been taken to "[e]nsure that private entities that offer facilities and services which are open or provided to the public take into account all aspects of accessibility for persons with disabilities” under Article 9, paragraph 2(b). ${ }^{260}$ The American veteran thus, in this way, benefits from the legal effects of the Convention in territory outside the United States.

State Party B, by contrast, has failed to take appropriate measures and its provisions for persons with disabilities thus do not satisfy the international obligations it accepted when acceding to the instrument. ${ }^{261}$ The American

${ }^{258}$ Art. 1, Responsibility of States for internationally wrongful acts: G.A.R. 56/83 (Dec. 12, 2001), annex.

259 The International Court determined that it is not necessary that the State to which obligations are owed under the Convention against Torture have a "special interest" in order to have standing to make a claim for an alleged breach of those obligations: "[A]ny State party to the Convention may invoke the responsibility of another State party with a view to ascertaining the alleged failure to comply with its obligations erga omnes partes.” Questions Relating to the Obligation to Prosecute or Extradite (Belg. v. Sen.), Judgment, 2012 I.C.J. 422, I 69 (July 20). Senegal had pleaded that Belgium would not have standing unless it were directly affected by the alleged breach, for example by demonstrating that the individual affected by the breach had Belgian nationality. Questions Relating to Obligation to Prosecute of Extradite (Belg. v. Sen.), Public Sitting, Verbatim Record, 16 (March 21, 2012), available at http://www.icj-cij.org/docket/files/144/16965.pdf (Amb. Thiam (Senegal), in response to questions presented by Judge Abraham). The Court's determination, which rejected, inter alia, the proposed requirement of nationality, turned on the character of the obligations. Id. It is doubtful, at least for the time being, that the obligations under the CRPD are to be imbued with a similar character.

${ }^{260}$ Convention Disabilities, supra note 1, at 77.

${ }^{261}$ In practice, it well may be a matter of contention whether the State Party's act or omission constitutes a breach. There is the usual scope for factual dispute-i.e., what measures has the 
veteran, injured by the breach of the Convention, brings this to the notice of the U.S. government, which, in turn, communicates to State Party B that State Party B's conduct is objectionable. The United States (assuming it, too, had ratified the Convention) is on firm legal ground when it makes the communication, because State Party B owes an obligation, under the Convention, to the United States.

It is thus doubly incorrect to say "all of the legal consequences which flow from [ratifying the CRPD] will be limited to the territory of the United States." ${ }^{262}$ Its legal consequences are found (i) in the territory of any State where the national legislation at the time of ratification of the Convention did not accord with its rules and (ii) at the international level as between the States Parties in the form of the obligations between them and in the form of the consequences arising when those obligations are breached.

\section{E. Article 7, Paragraph 2: "Best Interests of the Child"}

The objection that the CRPD would erode the right of families to educate their children at home was not raised during the drafting sessions. It instead was raised rather late in the day, principally by a former U.S. Senator, Richard Santorum. ${ }^{263}$ The objection is centered on Article 7, paragraph 2, of the Convention. Article 7, paragraph 2, says as follows: “Article 7: Children with Disabilities ... 2. In all actions concerning children with disabilities, the best interests of the child shall be a primary consideration."264 The concern, as expressed, is that the phrase "best interests of the child" might undermine the right of parents to raise their children in the manner they wish. In particular, those objecting to Article 7(2) assert that the provision would deprive American parents of the right to educate their children in the home (rather than in schools).

Dr. Farris, who carried the brief for the objectors in respect of Article

State Party in truth adopted. There is a further possible area of dispute because it is not clear that the legal rules contained in the Convention are to be applied the same way to every State Party. Article 4, paragraph 2, provides that "each State Party undertakes to take measures to the maximum of its available resources." Convention Disabilities, supra note 1 , at 74 (emphasis added). This suggests that the rules may apply differently, depending on each State Party's “available resources"-more stringently on a rich State, less so on a poor State. Such a differentiation in the application of a treaty rule well may present a delicate problem as State practice develops under the Convention. A number of States in the drafting work placed emphasis on the relevance of available resources to the application of the rules. See Working Group, supra note 42, Daily Summary, Vol. 3, \# 6, Jan. 12, 2004, 10-11 (observations of India); id., Vol. 3, \# 9, Jan. 15, 2004, p. 6 (observations of Sierra Leone).

262 S. EXEC. REP. No. 112-6, supra note 86, at 80; see also S. EXEC. REP. No. 113-12, supra note 213 , at 73 .

263 See Antonio Ginatta, What a Senate Vote for Disabilities Treaty Would Really Mean, THE HILL (Dec. 7, 2012, 7:30 PM), http://thehill.com/blogs/congress-blog/foreign-policy/271717what-a-senate-vote-for-disabilities-treaty-would-reall-mean.

${ }^{264}$ Convention Disabilities, supra note 1, at art. 7(2). 
7(2) in the Senate hearings, said that freedom of education, as it exists in the United States, would be undermined by the CRPD. Dr. Farris characterized the Convention as "promot[ing] the idea that government, not parents, have the ultimate voice in decisions concerning their children." 265 Dr. Farris further asserted that "[p]arents are assured of no rights in the education of their children" 266 and that under the CRPD "parental rights in the education of disabled children are supplanted by a new theory of governmental oversight and superiority." 267

Dr. Farris observed that Article 18, paragraph 4, of ICCPR and Article 13, paragraph 3, of the International Covenenant on Economic, Social, and Cultural Rights (ICESCR) both provide for "respect for the liberty of parents" in the matter of the "religious and moral education of their children in conformity with their own convictions." 268 This, indeed, is precisely what the Covenants say. The provisions concerning the liberty of parents and religious and moral education are explicit. There is nothing ambiguous about them. The provision of the CRPD under which Dr. Farris said the liberty of parents "will be eviscerated," ${ }^{269}$ by contrast, says, and only in general terms, that the best interests of the child will be "a primary consideration." ${ }^{270}$ An existing right, especially a fundamental right, is not displaced by inference. It is certainly not displaced by inference in a treaty concerned with a different subject matter. That the CRPD identifies the best interests of the child as one consideration-even "a primary" one-does not set aside all other considerations, including parental liberty. ${ }^{271}$ It certainly does not overturn the 1966 Covenants.

States know how to overturn treaties, and they know how to supplant them through subsequent practice, including subsequent treaty-making. They also know how to denote a hierarchy among relevant considerations in a treaty text. Article 7, paragraph 2, of the CRPD does none of these things. It provides no basis whatsoever for "eviscerating" the long-established liberty which it is Dr. Farris's concern to guard.

Two further points may be made in respect of Dr. Farris's testimony on Article 7, paragraph 2.

First, Dr. Farris said that "American law and international law are not compatible when it comes to parental rights." ${ }^{272}$ This is a puzzling way to characterize the legal situation. A State does not escape international law obligations by legislating its own rules which are "not compatible" with the

\footnotetext{
265 TREATY Doc. 112-7, supra note 11 , at 84.

266 S. EXEC. REP. NO. 113-12, supra note 253, at 213.

${ }^{267} I d$.

${ }^{268}$ Id., quoting ICCPR, art. 18(4) and ICESCR, art. 13(3).

${ }^{269}$ S. EXEC. REP. No. 112-6, supra note 86, at 86.

${ }^{270}$ Convention Disabilities, supra note 1, at art. 7(2).

${ }^{271} \mathrm{Id}$.

272 S. EXEC. REP. No. 112-6, supra note 86, at 87.
} 
international rules. ${ }^{273}$ If, in truth, "American law and international law" are not in accord-are "not compatible" - then the United States is in breach of international law. Presumably, this was not what Dr. Farris meant. If it had been, then he was accusing the United States of being in breach of international law! Instead, it seems that Dr. Farris meant that the CRPD, if the United States became party to it, would intrude against the right of American families to school their children as they see fit. That is to say, in Dr. Farris's view, an incompatibility would arise between U.S. law and the rules under Article 7, paragraph 2, of the CRPD, if the United States became party to the Convention.

This might appear to be a quibble over an infelicitous choice of words. However, there is a significant point. Taking Dr. Farris's words as recorded in the Senate Committee transcript, they say that there is an international law of parental rights. This is true, but only to an extent-namely, to the extent that States have become party to a conventional instrument establishing parental rights. Even assuming that the legal effect of Article 7, paragraph 2, is to deprive parents of the right to school their children as they see fit-an interpretation which, it has been submitted, is insupportable - the paragraph states a conventional rule, not a rule of customary international law. There is no indication, in the travaux or in the text, that the drafters of the CRPD thought that they were codifying an existing customary international law rule when they drafted Article 7(2), any more than the "respect for liberty of parents" was understood to be a customary rule at the time of the drafting or adoption of the Covenants. The rule contained in Article 7(2) of the CRPD is not a rule binding on the United States unless the United States becomes party to the Convention. So it is not accurate to say that a discordance exists between U.S. law and Article 7(2), for Article 7(2) is a conventional rule, not a customary rule, and, thus, Article 7(2) is not binding on the United States. The international law binding on a given State, unless the State chooses to accept a conventional rule that does so, contains no general regulation on the matter of schooling. When Dr. Farris implies that the United States is in breach of an international law rule that nullifies the liberty of parents to choose how their children are educated, he suggests a mistaken view of the character of the rules in the CPRD. In any event, as suggested, it is only by a tortured reading of the CRPD that a constraint can be discerned in its terms on the freedom of American families to determine the manner in which their

273 International Law Commission, supra note 258, at art. 3 (“Characterization of an act of a State as internationally wrongful.”). For the I.L.C.'s Commentary on art. 3, see THE INTERNATIONAL LAW COMMISSION'S ARTICLES ON STATE RESPONSIBILITY 86-90 (Crawford ed., 2002); see also, e.g., Técnicas Medioambientales Tecmed S.A. v. United Mexican States, ICSID Case No. ARB(AF)/00/2, Award, ๆ 120 (May 29, 2003), 10 ICSID Rep. 130 (2004); Compañía de Aguas del Aconquija S.A. and Vivendi Universal v. Argentine Republic, ICSID Case No. ARB/97/3, Decision on Annulment, qף 95-6 (July 3, 2002), 6 ICSID Rep. 340 (2002). 
children are schooled.

Finally, Dr. Farris acknowledges that a proposed declaration would "remove[] the possibility of direct judicial imposition of the provisions of the treaty." 274 It is difficult to see how the extreme effects Dr. Farris attributes to Article 7, paragraph 2, would be realized, if the United States withheld from its judges the power to apply it.

\section{POLICY GROUNDS FOR PARTICIPATING IN THE CRPD}

The observations set out in the preceding sections are concerned chiefly with questions of legal interpretation, with a view to assessing the objections raised in 2012 against ratification of the CRPD by the United States. The objections seem chiefly to have originated in policy concerns, but they were expressed by reference to law. Policy analysis is not analysis of a text in isolation. It requires analysis of the legal effects of the text when States apply it in practice. So a necessary antecedent to the policy analysis is a clear understanding of the legal effects of the text. The observations in the sections above have aimed to examine the critics' views as to the legal effects of the CRPD. It is submitted, that with the possible exception of the provisions of the CRPD that address situations of armed conflict, the text of the Convention does not justify the objections as a matter of law.

As a matter of policy, it is not convincing, however, to recommend adherence to a treaty simply on the ground that the treaty does no harm. To make the case for adherence, it must be shown that adherence carries some advantage. It is not the aim of the present article to review the policy background of CRPD in depth, much less to evaluate U.S. or international policy in respect of disabilities grosso modo. Nevertheless, some policy considerations that support U.S. adherence to CRPD may be instanced briefly.

\section{Leadership in standard-setting and best practices}

Adherence to CRPD would give the United States the chance to promote U.S.-defined best practices through participation in the international mechanisms that the CRPD establishes. The United States numbers among the top producers of goods and services related to persons with disabilities. Export promotion therefore is one of the benefits that would result from participating in the CRPD. It is noteworthy in this connection that South Korea, a State that exports technological products, proposed that the CRPD include a provision to encourage adoption of technology to assist disabled persons. ${ }^{275}$ The international market for such technology well could grow, if

274 S. EXEC. REP. NO. 112-6, supra note 86, at 82.

275 Working Group, supra note 42, Daily Summary, Vol. 3, \# 6, Jan 12, 2004, at 5 (observations of Republic of Korea). Note that Thailand singled out U.S. federal communications regulation as a 
more States were to adopt high-level standards for the rights of persons with disabilities. It also has been argued that the promotion of higher standards abroad would "level the playing field" for American businesses, which already are required to meet those standards but sometimes are placed at a disadvantage as against foreign competitors who are not. ${ }^{276}$

\section{Development objectives}

The United States, as a CRPD participant, would enhance its ability to promote disabilities legislation in other countries. This objective is consistent with the U.S. commitment to promoting development in general. In the Senate proceedings prior to the vote on ratification, it was observed in particular that the goal of promoting women's rights in developing countries would be served by U.S. participation in the treaty. ${ }^{277}$

\section{Rights of persons with disabilities in the international civil service}

U.S. participation would strengthen the CRPD as a means to promote the application of uniform standards in international organizations. The CRPD, as an instrument open to international organizations as well as to States, could serve as a standard-setting mechanism for the internal rules of international organizations. This would protect the interests of disabled people, including U.S. nationals, who are employed in the international civil service. It was noted in connection with the drafting work that U.N. facilities, for example, did not meet the standard for accessibility, which the Convention would require its parties to implement. ${ }^{278}$ Since the entry into

"good example" of how States can guarantee access for disabled people, id., Vol. 3, \# 9, Jan. 15, 2004, at 7, and the Ad Hoc Committee received information concerning U.S. provisions for education of persons with disabilities, Ad. Hoc. Comm., 6th Sess., Daily Summary, Vol. 7, \# 3 (Aug. 3, 2005), available at http://www.un.org/esa/socdev/enable/rights/ahc6sum3aug.htm, and information concerning accessibility requirements under U.S. law, Ad Hoc Comm., 6th Sess., Daily Summary, Vol. 7, \# 5, (Aug. 5, 2005), available at http://www.un.org/esa/socdev/enable/rights/

ahc6sum5aug.htm. A number of substantive provisions of the CRPD refer to the role of technology and technology development in enhancing the lives of persons with disabilities; Convention Disabilities, supra note 1, art. 4, १ๆ (f), (g) (general obligations); art. 9(2) १ๆ (g), (h) (accessibility); art. 20(b) (personal mobility); and art. 21(c) (freedom of expression and opinion, and access to information).

${ }^{276}$ S. EXEC. REP. NO. 112-6, supra note 86, at 34-35 (prepared statement of Judith Heumann); id,. at 8 . On Nov. 5, 2013, Sen. Robert J. Dole, in urging support, emphasised that the "treaty comes at no net cost to the United States. In fact, it will create a new global market for accessibility of goods.” S. EXEC. REP. NO. 113-12, supra note 253, at 44.

277158 Cong. Rec. S7370 (daily ed. Dec. 4, 2012) (statement of Sen. Tom Udall).

${ }^{278}$ Kanter, supra note 37, at 297; see also Melish, supra note 39, at 38. On the employment of U.S. nationals generally in the U.N. system, see U.S. Gov'T ACCOUNTABILITY OFFICE, GAO10-1028, U.S. EMPlOYMENT IN THE United NATIONS (2010). The United Nations Entity for Gender Equality and the Empowerment of Women indicates that the total number of U.S. 
force of the CRPD, a number of international organizations have instituted intramural programs for the implementation of its standards. ${ }^{279}$ Americans abroad more generally would also benefit as countries raise their disabilities standards to meet the international requirements, a point made in the Senate Report recommending ratification ${ }^{280}$ and reiterated by Tammy Duckworth, an Illinois Congresswoman and Lieutenant Colonel of the Illinois Army National Guard. Articulating the veteran's perspective, Congresswoman Duckworth drew attention to the benefits that the CRPD may have for veterans wishing to travel abroad. ${ }^{281}$

\section{Moral suasion}

The Department of State Special Advisor for International Disability Rights, Judith Heumann, in addressing the Senate Committee on Foreign Relations, noted the significance of U.S. participation in the CRPD for American foreign policy overall. According to the Special Advisor,

We will be a leading force in the drive to both improve lives and increase understanding and cooperation among States, as well as to impact the development of international standards on accessibility. Disability diplomacy will have a positive effect on overall bilateral and regional diplomacy of the United States, by allowing us to leverage the shared value of disability rights to promote dialogue on other issues of importance to U.S. foreign policy. We have found that

nationals, men and women, employed across all U.N. entities and agencies, from P1 to USG and GS levels, as of Dec. 31, 2009, was 4,028; U.N. Women, Gender Distribution of All Staff (Dec. 31, 2009), http://www.un.org/womenwatch/osagi/pdf/Nationalities2010

/NationalityTotals_Summary_2008-20091.pdf.

On inquiry by the author, suggested GAO official familiar with the GAO-10-1028 report said that a comprehensive count of U.S. nationals employed across all international organizations has not been compiled. An approximation would be the number of U.S. tax payers whose employers are exempt from federal income tax withholding under the U.S. Internal Revenue Code; 26 I.R.C. § 7701(a)(18) (2014) (public international organization income tax exemption for entities under the International Organizations Immunities Act, 22 U.S.C. $\S \S 288-288 f$ (2014)). For the list of exempt organizations (to which further organizations may be added by Executive Order), see 8 C.F.R. $\S \S 316.20($ b)-(c) (2015).

279 See, e.g., Katherine Guernsey, et. al., World BANK, CONVENTION ON THE Rights OF Persons With Disabilities: ITS IMPlementation AND RELEVANCE FOR THE WORLD BANK (2007), available at http://siteresources.worldbank.org/SOCIALPROTECTION/Resources/ SP-Discussion-papers/Disability-DP/0712.pdf (presenting overview of World Bank measures to ensure implementation in client countries).

280 S. EXEC. REP. No. 112-6, supra note 86, at 2 (“Americans with disabilities often face significant and, at times, prohibitive, barriers when they travel, work, serve, study and reside in other countries.”).

${ }^{281}$ S. EXEC. REP. NO. 113-12, supra note 253, at 49-52 (testimony of Tammy Duckworth). 
inclusion of disability rights in the work of the State Department amplifies our ability to achieve our broader foreign policy objectives. However, this work is unduly hampered by our not having a seat at the table as a State Party. ${ }^{282}$

There is no doubt that the United States already exercises a major influence across the world in the field of the rights of persons with disabilities. It is also the case that participation in CRPD would increase American influence in that field. Not all policymakers place the same value on the power of moral suasion in international affairs. Yet the United States has long sought to conduct itself as an international "good citizen," promoting its own interests, as all States do, but doing so, to the extent possible, with a view to the benefits its policies may have for others and for the system of international relations in general. The United States long has encouraged other States to model their conduct accordingly. Having "a seat at the table" by participating in the CRPD would continue this tradition of American foreign policy.

\section{CONCLUSIONS}

The transmittal in 2012 to the U.S. Senate of the U.N. Convention on the Rights of Persons with Disabilities presented a classic case of treaty politics in an American framework. A number of Senators were opposed to further participation by the United States in the U.N. human rights system. They numbered over a third of the Senate and so prevented ratification of the CRPD. The objections to the CRPD would seem to have derived in large part from a general ambivalence toward international organization. Senators expressed their objections, directly and by associating themselves with the testimony of several experts, in legal terms as well. The present article has considered the legal objections on their terms.

Curiously, the one objection having an arguable legal basis, though raised earlier in the drafting work, was not articulated in any meaningful way during the Senate proceedings. This is the objection that the CRPD, in particular preambular paragraph (u) and Article 11, intrude upon humanitarian law as applicable in armed conflict. The difficulties associated with those two provisions have been noted. ${ }^{283}$ They merited consideration by the Senate.

The focal points in the Senate's consideration of the CRPD, instead, were abortion, home schooling, and the relation between the CRPD and existing protections under U.S. law for persons with disabilities. It was also

282 S. EXEC. REP. No. 112-6, supra note 86, at 34; see also Melish, supra note 39, at 47 n. 25.

283 See infra para. (u) and Art. 11 
suggested that the CRPD would impose an unnecessary compliance burden on the United States. The observations set out above in respect of each of these objections may be summarized here in brief.

Taking the matter of compliance burden first, there are two areas in which the CRPD might impose a compliance burden on a State Party. First, a State Party must take steps that its national legislation and practices are in accord with CRPD rules, standards, and principles. ${ }^{284}$ Second, a State Party must participate in certain procedures and institutions established by the CRPD. ${ }^{285}$ Not all CRPD mechanisms are mandatory, but some are (e.g., the reporting requirement under CRPD Article 35). ${ }^{286}$ The scope of mandatory mechanisms depends on whether a State Party has adhered to the Optional Protocol, and, if so, whether it has accepted all provisions of the Protocol. ${ }^{287}$ The United States, it is widely agreed, would not incur a compliance burden in respect of national legislation: existing U.S. legislation meets or exceeds the standards contained in CRPD. ${ }^{288}$ As for the Optional Protocol, the United States would not be required to adopt it. ${ }^{289}$ As for the remaining requirements (reporting under Article 35), these are no more onerous than those already accepted by the United States as a participant in other human rights treaties. $^{290}$

A distinct objection relates to causes of action in national court. It is extremely unlikely that the CRPD would introduce new causes of action available to litigants in the federal or state courts of the United States. It would be all the more unlikely, if the United States ratified the CRPD with reservations similar to those which it has adopted in connection with other human rights treaties (e.g., ICCPR). ${ }^{291}$ As one plaintiff pleading the CRPD in a case before a federal district court learned in 2011, a given federal statutory provision did not confer "any rights enforceable... for violations of international law." 292 The CRPD is among various human rights instruments that "do not create federal causes of action." 293 The few references that courts in the United States have made to the CRPD to date have been for illustrative

\footnotetext{
${ }^{284}$ See Convention Disabilities, supra note 1.

${ }^{285} I d .$.

${ }^{286} I d$.

287 See Optional Protocol, supra note 15.

288 See Convention Disabilities, supra note 1.

${ }^{289}$ See Optional Protocol, supra note 15.

290 See Convention Disabilities, supra note 1,

291 The practice to date in U.S. courts tends to confirm this conjecture. See, as noted above, note 25, human rights groups' amicus curiae submission in Smith et al v. City of Detroit, Bankruptcy Case No. 13-53846, Ad. Proc. No. 14-04732, Feb. 3, 2015. References to the CRPD in U.S. courts have not been to establish new causes of action.

${ }^{292}$ Knapp v. Cate, F. Supp.2d (unreported) (McAuliffe, U.S. Mag. J.) (Nov. 8, 2011) p. 7.

293 Townsend v. New Jersey Transit and Amalgamated Transit Union, F.Supp. 2d (unreported) (Brown, CJ) (Sept. 27, 2010) p. 5.
} 
or persuasive purposes, not as binding authority. ${ }^{294}$

It must be said that a degree of confusion emerges from the objections, as to how the CRPD would affect municipal law. Those advising against ratification suggest, at once, that the Convention would do nothing to change the law; ${ }^{295}$ would add new disabilities rules at variance with existing U.S. law; ${ }^{296}$ and would cancel or derogate existing U.S. legal protections. ${ }^{297}$ It is also said that the Convention would give Americans abroad no causes of action under the municipal legal systems of other States Parties ${ }^{298}$ —but it is alleged that private litigants in the United States will have new causes of action under the Convention's rules in U.S. courts. ${ }^{299}$ The objections in respect of municipal law, then, are more a mélange than a coherent argument. It might be pleaded, in defense of the objections, that the application of the CRPD at the municipal level is simply too uncertain for one to predict its effects. This, however, is not convincing. The CRPD is one of a series of human rights instruments, several of which have been in force in the United States for some time. The United States signed the ICCPR in 1977, for example, and ratified it in $1992 .{ }^{300}$ This did not result in a substantial compliance burden as measured by actions in domestic court, ${ }^{301}$ even as some scholars called for the ICCPR's direct application in U.S. law. ${ }^{302}$ Those instruments, it is submitted, have not introduced undue burdens on the U.S. legal system, and one should not anticipate that the CRPD would either.

The objection in respect of home schooling was addressed above. ${ }^{303} \mathrm{It}$ is difficult to see how that objection finds support in the text of the treaty. It would certainly be open to the United States to adopt a reservation or declaration to clarify that nothing in the CRPD derogates the existing parental liberties enshrined in the 1966 Covenants and under U.S. law. The United States has adopted such an approach in the past. To give the main example,

\footnotetext{
294 See, e.g., In re Guardianship of Dameris L., 38 Misc. 3d 570, 579-580; 956 N.Y.S.2d 848, 855 (New York Surrogate's Court, Booth Glen, J.) (Dec. 31, 2012). Judge Booth Glen earlier had referred to the CRPD to similar effect. See In re Mark C.H., 38 Misc. 3d 765, 786; 906 N.Y.S.2d 419, 434 (New York Surrogate's Court, Booth Glen, J) (Apr. 21, 2010). International Covenant on Civil and Political Rights (last updated June 8, 2015), https://treaties.un.org/pages/ShowMTDSGDetails.aspx?src=UNTSONLINE\&tabid=2\&mtds g_no=IV-4\&chapter=4\&lang=en\#Participants

${ }^{301}$ On the ICCPR in the United States, see Anja Seibert-Fohr, "Domestic Implementation of the International Covenant on Civil and Political Rights Pursuant to its article 2 para. 2," 5 Max Planck United Nations Yearbook 400, 443-454 (2001).

302 See e.g., John Quigley, “The International Covenant on Civil and Political Rights and the Supremacy Clause,” 42 DePaul L. Rev. 1287, 1309-1310 (1993).

303 See supra Part III.
} 
Article 19 of the ICCPR sets out a right to freedom of expression and associated rights. ${ }^{304}$ ICCPR Article 20 qualifies the rights, by obliging parties to the Covenant to prohibit "propaganda for war" and "advocacy of national, racial or religious hatred that constitutes incitement to discrimination, hostility or violence." ${ }^{305}$ Adherence to ICCPR Article 20 by the United States would appear to have imposed on U.S. law a lower standard of protection for the right of free speech and association than exists under the Constitution and laws of the United States. To avoid the possibility of a lower standard, the United States, when it ratified ICCPR, adopted (inter alia) a reservation in respect of freedom of speech. ${ }^{306}$ According to the reservation, "Article 20 does not authorize or require legislation or other action by the United States that would restrict the right of free speech and association protected by the Constitution and laws of the United States." 307 It is open to the United States to adopt a similar "laws of the United States" statement in connection with ratification of the CRPD. Such a statement respecting the CRPD would be termed more accurately a declaration than a reservation, as it would not be reserving or changing the application of any part of the CRPD. It would instead reiterate or clarify a position already clear in the treaty: the treaty does not require the United States to diminish the protections afforded under national law to persons with disabilities, nor does it erode any other right under U.S. law, such as the right of parents to choose how to educate their children.

C. Boyden Gray, in testimony on November 21, 2013, made a similar point. ${ }^{308}$ The former White House counsel and U.S. ambassador to the EU said, "it is essential that we include reservations, understandings and declarations, or RUDs, to tailor this treaty to our concepts of equal opportunity and non-discrimination., ${ }^{309}$ He drew attention to the federalism reservation, "not[ing] with approval that the Obama Administration made its Federalism provision a Reservation, rather than an Understanding." $310 \mathrm{He}$ affirmed that "[t]he claims that somehow ratification of the Disabilities Treaty will undermine U.S. sovereignty are simply false”. 311

The objection in respect of Article 25 relates more obviously to the text than the objection in respect of home schooling; the text says nothing about

\footnotetext{
${ }^{304}$ ICCPR, supra note 63, at 7.

${ }^{305} \mathrm{Id}$. at 8.

${ }^{306}$ International Covenant on Civil and Political Rights, U.S. Reservation 1 upon Ratification, deposited June 8, 1992, 1676 U.N.T.S. 543 (entered into force Sept. 8, 1992); see also International Convention on the Elimination of All Forms of Racial Discrimination, U.S. Reservations upon Ratification, deposited Oct. 21, 1994, 1830 U.N.T.S. 284-85 (entered into force Nov. 20, 1994).

${ }^{307} \mathrm{Id}$.

308 S. EXEC. REP. No. 113-12, supra note 253, at 173 (testimony of C. Boyden Gray).

${ }^{309}$ Id.

${ }^{310} \mathrm{Id}$.

${ }^{311}$ Id. at 174 .
} 
home schooling but does refer to "sexual and reproductive health."312 Several States share the American objectors' concern in that connection. Iran, for example, stated during the drafting work that it "accepts the phrase 'sexual and reproductive health' with the understanding that the phrase does not include abortion, and that its use in article 25 (a) does not create any abortion rights and cannot be interpreted as constituting promotion of abortion.”313

Malta, on signing the Convention, adopted the following interpretative statement:

Malta understands that the phrase "sexual and reproductive health" in Art 25(a) of the Convention does not constitute recognition of any new international law obligation, does not create any abortion rights, and cannot be interpreted to constitute support, endorsement, or promotion of abortion. Malta further understands that the use of this phrase is intended exclusively to underline the point that where health services are provided, they are provided without discrimination on the basis of disability. ${ }^{314}$

There is also the Polish reservation, which states, "The Republic of Poland understands that Articles 23.1(b) and 25(a) shall not be interpreted in a way conferring an individual right to abortion or mandating [a] state party to provide access thereto." 315 In a related vein, Article 10 ("Right to Life") attracted a declaration by the Netherlands as follows: "The Kingdom of the Netherlands acknowledges that unborn human life is worthy of protection. The Kingdom interprets the scope of Article 10 to the effect that such protection - and thereby the term 'human being' - is a matter for national legislation." ${ }^{316}$ Under the law of treaties (subject to the treaty explicitly adopting a different position),

[A] reservation is considered to have been accepted by a State if it shall have raised no objection to the reservation by the end of a period of twelve months after it was notified of

312 Convention Disabilities, supra note 1, art. 25(a).

${ }^{313}$ G.A. Res. 61/76, supra note 5, at 5 (Mrs. Hasteh (Iran)).

${ }^{314}$ Convention Disabilities, supra note 1, Malta's Declarations and Reservations, available at https:// treaties.un.org/Pages/ViewDetails.aspx?src=TREATY\&mtdsg_no=iv-15\&chapter=4\&lang=en; see also Ad Hoc Comm., 4th sess., Daily Summary, Vol. 5, \# 5 (Aug. 27, 2004), available at http://www.un.org/esa/socdev/enable/rights/ahc4sum27aug.htm (observation of Costa Rica, concurring in substance on a point about abortion and the words "sexual and reproductive health" (i.e., that the words do not establish any international law right to abortion).

${ }^{315}$ U.N., Convention on the Rights of Persons with Disabilities (last updated June 8, 2015), https://treaties.un.org/pages/ShowMTDSGDetails.aspx?src=UNTSONLINE\&tabid=2\&mtds g_no=IV-15\&chapter=4\&lang=en\#Participants.

${ }^{316} I d$. (emphasis added). 
the reservation or by the date on which it expressed its consent to be bound by the treaty, whichever is later. ${ }^{317}$

No Party at the time the present article went to press had raised objection to the Maltese or Netherlands declarations or to the Polish reservation. Well-documented travaux préparatoires (several years' worth of Working Group and Ad Hoc Committee daily summaries) demonstrate the widespread acceptance by States participating in the drafting process that indeed CRPD Article 25(a), as Malta said, "does not create any abortion rights" at the international level, nor does it "constitute support, endorsement, or promotion of abortion." 318

This leaves the question of humanitarian law. A reservation to preambular paragraph (u) and Article 11 would concern a very small part of the Convention. Only the latter (the reservation to Article 11 would concern an operative provision. Article 11 is severable from the rest of the Convention. That is to say, Article 11 is not integral to the CRPD in such a way that reserving its effect would negate or otherwise interfere with other operative provisions. Moreover, Article 11 extends CRPD into the field typically occupied by international humanitarian law. Its character as an extension beyond the main core of human rights law further supports the conclusion that to reserve the application of Article 11 would not interfere with the object or purpose of the Convention: the CRPD was not intended to be a new branch of the law of armed conflict. ${ }^{319}$

Robert Dole, former Majority Leader of the U.S. Senate, in a letter to the Senate Committee on Foreign Relations in July 2012, wrote in support of the U.N. Convention on the Rights of Persons with Disabilities. ${ }^{320}$ Senator Dole told the Senate that "[n]ow is the time to reaffirm the common goals of equality, access, and inclusion for Americans with disabilities-both when those affected are in the United States and outside of our country's borders." ${ }^{321}$ It is fitting that a distinguished former leader of the Senate who, as a disabled veteran, had been instrumental in securing protections under

\footnotetext{
${ }^{317}$ Vienna Convention, supra note 21, at 337. Whether Malta calls its statement a "declaration” or a "reservation" is not material to its legal effect. Id. at 333.

${ }^{318} \mathrm{Id}$.

319 This conclusion is further supported by reference to the preamble. In identifying the object and purposes of the Convention, preambular paragraphs (b), (c), and (d) refer to the main human rights treaties and principles-not to humanitarian law.

${ }^{320}$ S. EXEC. REP. No. 112-6, supra note 88, at 29 (letter of Robert Dole, read into the record by Sen. John McCain).

${ }^{321}$ Id.
} 
American law for persons with disabilities, lent his voice to the CRPD. ${ }^{322}$ Owing in part to Senator Dole's support, the CRPD received favorable votes in 2012 from members of both political parties in the Senate and was nearly ratified.

The Senate vote on the CRPD took place-as have all modern Senate votes on treaties - in light of a long tradition of caution toward international commitments. $^{323}$ American foreign policy exists in balance between scepticism and engagement--scepticismtoward new legal instruments and engagement in international law-making. At times, such as when it instigated but then declined to ratify the Covenant of the League of Nations or, nearly a century later, when it played a central role in drafting the Rome Statute of the International Criminal Court but chose not to participate in that instrument, the United States has shifted rapidly from the closest engagement to a determined distance. Some treaties seek to re-shape the structure of international relations. Others have much less controversial aims. A policymaker, when presented a new treaty, inevitably will consider a range of policy and legal questions relevant to U.S. participation. It is submitted here that, in balance, the legal questions raised by its critics do not justify rejection of the Convention on the Rights of Persons with Disabilities.

\footnotetext{
322 See 136 Cong. REC. S17376 (daily ed. July 13, 1990) (remarks on the Senate floor regarding passage of the Americans with Disabilities Act, Pub. L. No. 101-336, 104 Stat. 327 (codified at 42 U.S.C. §§ 12101-12213 (1994), amended; Public Law 110-325, 122 Stat. 3553 (2008))); George Bush, Remarks at the Signing of the ADA (July 16, 1990) (transcript available at http://www.eeoc.gov/eeoc/history/35th/videos/ada_signing_text.html); see also Bob Dole, Are We Keeping America's Promises to People with Disabilities? 79 IowA L. REV. 925, 927-28 (1994); see also 115 Cong. REC. 8818, (daily ed. Apr. 14, 1969) (first floor speech as U.S. Senator)("When more of this emphasis on the individual better influences the agencies and professions dealing with the handicapped, I believe we can begin to open new, more meaningful vistas for more persons with handicaps.”).

${ }^{323}$ For the locus classicus, see George Washington, Farewell Address (Sept. 19, 1796), http://avalon.law.yale.edu/18th_century/washing.asp ("Why forego the advantages of so peculiar a situation? Why quit our own to stand upon foreign ground? Why, by interweaving our destiny with that of any part of Europe, entangle our peace and prosperity in the toils of European ambition, rivalship, interest, humor or caprice?

It is our true policy to steer clear of permanent alliances with any portion of the foreign world; so far, I mean, as we are now at liberty to do it; for let me not be understood as capable of patronizing infidelity to existing engagements. I hold the maxim no less applicable to public than to private affairs, that honesty is always the best policy. I repeat it, therefore, let those engagements be observed in their genuine sense. But, in my opinion, it is unnecessary and would be unwise to extend them.”).
} 